\title{
Review
}

\section{RNA Flow Cytometry for the Study of T Cell Metabolism}

\author{
Alessandra Rossi ${ }^{1,+}$ (D) Ilenia Pacella ${ }^{1,+}$ and Silvia Piconese ${ }^{1,2, * \mathbb{D}}$ \\ 1 Department of Internal Clinical Sciences, Anaesthesiology and Cardiovascular Sciences, Sapienza University \\ of Rome, 00161 Roma, Italy; alessandra.rossi@uniroma1.it (A.R.); ilenia.pacella@uniroma1.it (I.P.) \\ 2 Istituto Pasteur Italia-Fondazione Cenci Bolognetti, 00161 Roma, Italy \\ * Correspondence: silvia.piconese@uniroma1.it \\ + Equally contributing authors.
}

Citation: Rossi, A.; Pacella, I.;

Piconese, S. RNA Flow Cytometry for the Study of T Cell Metabolism. Int. J. Mol. Sci. 2021, 22, 3906. https:// doi.org/10.3390/ijms22083906

Academic Editors: Rune Smaaland and Stefano Papa

Received: 13 February 2021

Accepted: 7 April 2021

Published: 9 April 2021

Publisher's Note: MDPI stays neutral with regard to jurisdictional claims in published maps and institutional affiliations.

Copyright: (c) 2021 by the authors. Licensee MDPI, Basel, Switzerland. This article is an open access article distributed under the terms and conditions of the Creative Commons Attribution (CC BY) license (https:/ / creativecommons.org/licenses/by/ $4.0 /)$.

\begin{abstract}
T cells undergo activation and differentiation programs along a continuum of states that can be tracked through flow cytometry using a combination of surface and intracellular markers. Such dynamic behavior is the result of transcriptional and post-transcriptional events, initiated and sustained by the activation of specific transcription factors and by epigenetic remodeling. These signaling pathways are tightly integrated with metabolic routes in a bidirectional manner: on the one hand, $\mathrm{T}$ cell receptors and costimulatory molecules activate metabolic reprogramming; on the other hand, metabolites modify $\mathrm{T}$ cell transcriptional programs and functions. Flow cytometry represents an invaluable tool to analyze the integration of phenotypical, functional, metabolic and transcriptional features, at the single cell level in heterogeneous $\mathrm{T}$ cell populations, and from complex microenvironments, with potential clinical application in monitoring the efficacy of cancer immunotherapy. Here, we review the most recent advances in flow cytometry-based analysis of gene expression, in combination with indicators of mitochondrial activity, with the aim of revealing and characterizing major metabolic pathways in T cells.
\end{abstract}

Keywords: T cells; metabolism; mitochondria; RNA; flow cytometry

\section{Introduction}

The field of immunometabolism, which is the study of how metabolic pathways affect immune cell functions, is continuously growing [1]. While the analysis of immune cell phenotype, functions and gene expression profile is possible, even at the single cell level, thanks to state-of the-art technologies such as multiparameter flow cytometry and nextgeneration sequencing, the study of metabolite content and flux in immune cells is more difficult to perform, due to technical constraints such as the amount of required material. However, especially in T cells, much information is available regarding the transcriptional control of metabolism: indeed, key transcription factors promote the expression of genes involved in specific metabolic pathways, thus dictating the immune as well the metabolic program of T cells in different states [2]. Therefore, the analysis of the expression of selected genes may provide relevant information on the metabolic profile of a certain cell type or stage. This analysis can be performed through RNA flow cytometry: this approach, which can be easily performed in any laboratory provided with a flow cytometer, allows for the analysis of selected mRNAs at the single cell level, in combination with other flow cytometry-based assays, such as surface and intracellular marker staining or mitochondrial mass/polarization analysis. In this review, we will first provide an overview of recent knowledge in the field of $\mathrm{T}$ cell metabolism, with a special focus on its transcriptional control. Then, we will illustrate how RNA flow cytometry works and how it can be combined with conventional flow cytometry, in order to obtain a complete picture of the immunometabolic profile of T cells at the single-cell level. Finally, we will propose an example of this procedure applied to the study of regulatory T cells (Tregs) and demonstrate the compatibility of RNA flow cytometry with the analysis of intranuclear marker expression and of mitochondrial mass. 


\section{Overview of T Cell Metabolism}

Immune cells harbor a high level of plasticity to sustain the broad range of immune functions. A growing body of literature has described a central role for cellular metabolism in regulating the transcriptional reprogramming accompanying the different phases of leukocyte functional states [2]. In T cells, transition through the different activation states is accompanied by the active reprogramming of cellular metabolism. Mature naive T cells rely mainly on oxidative phosphorylation (OXPHOS) to maintain their quiescent state while activated $\mathrm{T}$ cells sustain their growth by switching to a glycolytic-lipogenic metabolism, characterized by the increased uptake of glucose (and other nutrients) from the extracellular environment, the generation of ATP from substrate-level phosphorylation during glycolysis, the conversion of pyruvate into lactate, and biosynthesis of macromolecules for cell growth and division. Memory T cells resume the OXPHOS but, as compared to naive cells, they are "metabolically primed" for a glycolytic switch, a combination that ensures both longterm survival and a prompt response to an antigen recall $[3,4]$. These metabolic changes are directly orchestrated by the triggering of the T cell receptor (TCR) and costimulatory molecules. In naive T cells, the concerted engagement of TCR and CD28 by cognate molecules on antigen presenting cells (APCs) promote glucose uptake by upregulating the membrane expression of the glucose transporter Glut1 through the mammalian target of rapamycin (mTOR) pathway [5-7]. These effects are counteracted by immune inhibitory molecules, including CTLA4 and PD-1, that brake immune responses to a halt by inhibiting glucose uptake and metabolism as well as by promoting endogenous fatty acid oxidation (FAO) [8].

FAO and mitochondria play important roles in both effector and memory $\mathrm{T}$ cells ${ }^{\prime}$ metabolism [9]. Mitochondria are essential for the development of memory responses since remodeling of these organelles is required to maintain adequate levels of FAO that allow memory $\mathrm{T}$ cell survival. Indeed, effector and memory $\mathrm{T}$ cells feature distinct mitochondrial patterns underlying the different engagement of FAO and OXPHOS in these activation states. The enhanced aerobic glycolysis rate upon naive $\mathrm{T}$ cells activation is accompanied in effector $\mathrm{T}$ cells by mitochondria fission that leads to cristae expansion and thus to a reduction in the electron transport chain (ETC) efficiency. On the contrary, memory T cells feature networks of fused mitochondria that tighten cristae and closely associate ETC complexes, ultimately fostering FAO and OXPHOS [10].

More recently, a role for cardiolipins, a class of phospholipids specifically associated with the internal mitochondrial membrane, has been uncovered in CD8 T cell activation and differentiation into memory cells. CD8 T cells deficient for the cardiolipin-synthesizing enzyme PTMPT1 (protein tyrosine phosphatase mitochondrial 1) show defective responses to antigens in vivo both at the induction and at the reactivation phase and fail to achieve complete pathogen clearance. Similarly, the genetic deficiency of Tafazzin, an enzyme involved in cardiolipin remodeling (as a protective mechanism from oxidative damage), also results in CD8 T cells with reduced proliferative ability and functionality and in a reduced number of central memory CD8 T cells in vivo [11].

\section{A Closer Look at the Metabolism of Tregs}

Regulatory $\mathrm{T}$ cells (Tregs) are now recognized as a specialized CD4 $\mathrm{T}$ cell subset essential for immune homeostasis, as well as for protection from autoimmunity and excessive inflammation. Although originally described as anergic cells [12], Tregs can be highly proliferative, especially in specific circumstances in vivo, such as the expansion occurring in neonatal life $[13,14]$ or in tissue injury and cancer $[15,16]$.

The metabolic dynamics in Tregs have not yet been completely clarified, most likely because of the intrinsic heterogeneity and plasticity that characterizes this immune subset. For instance, the differentiation of Tregs from conventional CD4 T cells (Tconvs) in the periphery seems to occur when the glycolysis-lipogenesis pathway is blocked. Accordingly, in vitro differentiation of Tregs from Tconvs can be induced by rapamycin, a well-known inhibitor of mTOR [17]. Nevertheless, additional studies on natural Tregs have demonstrated 
that the mTOR-driven glycolytic-lipogenic metabolism plays a pivotal role in Treg expansion and fitness. Indeed, mice carrying the Treg-intrinsic ablation of mTOR spontaneously develop a severe autoimmune and inflammatory systemic disease $[18,19]$, secondary to a decreased glycolytic rate and thus reduced competitive fitness at the systemic level in Tregs [18].

An additional factor affecting Tregs metabolism is probably the activity at which they are analyzed. Indeed, many studies suggest that some "division of labor" exists between different metabolic pathways in Tregs, with glycolysis mainly involved in migration and OXPHOS in suppressive functions [20]. The engagement of pro-migratory stimuli, such as lymphocyte function-associated antigen 1 (LFA-1) or CD28, enhances the glucose uptake and glycolytic rate while promoting migration through the activation of mTORC2 and, ultimately, the hexokinase isoenzyme glucokinase (GCK) [21].

Accumulating data have linked mitochondrial activity, and thus OXPHOS, to Tregsuppressive functions. In a recent report, mice with Treg-restricted ablation of the mitochondrial complex III developed a severe systemic disease, characterized by apparently normal Treg numbers but defective Treg competitive fitness and Treg suppression at the systemic level [22]. Other genes related to mitochondria functions, including the complex I of electron transport, have been recognized as important elements for Treg suppressive function $[23,24]$. Besides fueling Treg functions, the proficient mitochondrial metabolism may control their suppressive functions through mechanisms not strictly related to OXPHOS. In a recent paper, Field et al. have proposed that mitochondria integrity represents a checkpoint for Treg suppressive activity. Specifically, the Treg-restricted deficiency of the fatty acid transporter FABP5 results in enhanced suppressive functions by promoting IL-10 release. The underlying mechanism involves the release of mtDNA in the cytoplasm that activates IFN-I-related genes through the cyclic AMP-GMP synthase-Stimulator of interferon genes (cGAS-STING) pathway. Interestingly, the phenotype of FABP5-deficient Tregs is recapitulated in the tumor microenvironment by the reduced lipid availability. An IFN-Irelated signature is described in tumor-infiltrating Tregs, suggesting that mitochondrial damage may exacerbate Treg suppressive functions in this setting [25].

\section{Analysis of Mitochondrial Metabolism in T Cells: Role in the Tumor Microenvironment}

It is now well established that mitochondrial morphology and functions play crucial roles in a variety of immune functions and immune cell types. Along T cell differentiation, mitochondria undergo extensive remodeling that is tightly intermingled with functional reprogramming. Memory CD8 T cells have a higher spare respiratory capacity than effector and naive cells, and this is associated with higher mitochondrial mass and fatty acid oxidation [26]. Moreover, memory cells display mitochondria with fused morphology, and conversely mitochondrial fusion supports memory T cell development [10]. Costimulation through the CD28 during T cell priming is the key event that drives fatty acid oxidation, mitochondrial elongation and respiratory capacity in developing memory T cells [9].

Within the tumor microenvironment, $\mathrm{T}$ cells progressively lose their effector functions undergoing metabolic and epigenetic reprogramming, a process known as exhaustion [27]. Several studies demonstrate that mitochondrial alterations significantly contribute to tumorassociated T cell exhaustion. In mouse tumor models, tumor-infiltrating CD8 T cells display an accumulation of depolarized mitochondria that are not efficiently cleared because of defective mitophagy; these cells have functional impairment and epigenetic reprogramming that are compatible with exhaustion [28,29]. The balance between mitochondrial fusion and fission may dictate the fate of $\mathrm{T}$ cell activity: supporting this view, the manipulation of mitochondrial pro-fission (Drp1) or pro-fusion (Opa1) proteins can modulate T cell effector functions and affect their exhaustion in the tumor microenvironment [10,30]. Whether CD4 $\mathrm{T}$ cell activation and effector functions are similarly affected by mitochondrial dynamics is less clear. In a mouse model of experimental autoimmune encephalomyelitis, inhibiting mitochondrial fission suppressed T helper 1 and 17 polarization, thus alleviating disease 
severity [31]: these data support the idea that mitochondrial fission is required for CD4 T cell effector functions, similarly to CD8 T cells.

Several factors are recognized to drive mitochondrial dysfunctions in tumor-infiltrating lymphocytes (TILs). In human cancer, the tumor microenvironment accumulates longchain fatty acids that are incorporated (and not metabolized) by CD8 T cells: this drives functional impairment and compromises mitochondrial integrity and polarization, probably due to the disruption of mitochondria-associated ER membrane that is induced by palmitate overload [32]. However, not all T cells are equal. Indeed, in another experimental setting, fatty acid uptake by Tregs through the transporter CD36 was rather required for their suppressive function in tumors, and also for proper mitochondrial biogenesis and oxidative phosphorylation [33]. Recent data have highlighted the role of systemic metabolism in shaping local immunometabolic responses in tumors: indeed, obesity leads to increased fatty acid uptake by tumor cells but not by $\mathrm{T}$ cells, promoting their functional exhaustion [34]. Hypoxia in the tumor microenvironment is another factor that may play a key role in T cell exhaustion: indeed, severe hypoxia drives mitochondrial dysfunctions and ROS formation, and this promotes the development of an exhausted phenotype [35].

The information about mitochondrial activities in $\mathrm{T}$ cell functions has been growing in the latest years. This advance would not be possible without the usage of staining techniques at the single cell level. Besides electron microscopy that allows a detailed analysis of mitochondria ultrastructure, several fluorescence-based staining techniques have been developed to study these organelles and assess their functional state. Maintenance of the proper potential across the inner and outer membranes allows mitochondria to fulfil their tasks [36]; therefore, membrane depolarization is a good indicator of mitochondrial dysfunction [37,38].

The available staining techniques identify cells with healthy, metabolically active mitochondria through fluorescent reagents that accumulate in active mitochondria with intact membrane potentials and are suitable both for imaging microscopy and flow cytometry. These fluorescent probes can be classified into two main categories according to their ability to detect the mitochondrial membrane potential at a specific time point or its dynamic changes over time.

The first category includes the MitoTracker probes, small $(<1 \mathrm{kDa})$ cell-permeant mitochondrion-selective dyes containing a thiol-reactive chloromethyl moiety that forms covalent bonds with the mitochondrial thiols. As a consequence of these irreversible reactions, MitoTracker probes can only be used to detect mitochondrial membrane potential at the time of loading in live cells, with active mitochondria exhibiting brighter fluorescence compared to apoptotic mitochondria. The second category includes fluorescent dyes that show potential-dependent accumulation in mitochondria and change their emission properties upon depolarization, thus allowing for the monitoring of the potential. Some assays are based on dual-emission dyes for a ratiometric assessment of the membrane depolarization. For instance, when the JC-1 (tetraethyl benzimidazolyl carbocyanine iodide) dye accumulation within the mitochondria is high enough in concentration J-aggregates form, and there is an emission shift from the monomer (green, $\sim 529 \mathrm{~nm}$ ) that is prominent at lower dye concentrations to J- aggregates (red, $~ 590 \mathrm{~nm}$ ) which are formed as the dye concentration increases. Consequently, mitochondrial depolarization is indicated by a decrease in the red/green fluorescence intensity ratio. With a similar mechanism, the DiOC2(3) (3,3'-Diethyloxacarbocyanine iodide) shifts from the green to the far-red emission (above $650 \mathrm{~nm}$ ). Dynamic changes of mitochondrial membrane potential can be monitored by single emission molecules, such as (tetramethylrhodamine methyl ester) (TMRM) and DiIC1(5). TMRM (tetramethylrhodamine methyl ester) or the related TMRE (tetramethylrhodamine ethyl ester) are small, cell-permeant dyes that accumulate in active mitochondria. If the cells are healthy and have functioning mitochondria, the signal is bright. Upon the loss of the mitochondrial membrane potential, TMRM and TMRE accumulation ceases and the signal dims or is lost from the mitochondria. 


\section{Control of T Cell Metabolism at the Transcriptional Level}

T cell activation through the TCR and costimulatory and cytokine receptors initiates a cascade of phosphorylation and calcium flux events that finally end in the activation of transcription factors and thus in gene expression. This signaling pathway concomitantly induces the activation of mTOR: this factor translates the immune stimulation into a metabolic switch through a top-down pathway. Conversely, several metabolites have been shown to affect immune signals, and this can be seen as a bottom-up pathway [2]. In both cases, the modulation of immune and metabolic $\mathrm{T}$ cell functions may imply de novo gene expression: indeed, most of these metabolic sensors act through a combination of post-translational, post-transcriptional and transcriptional events. Therefore, studying gene expression can provide significant insights into the metabolic status in which $\mathrm{T}$ cells enter under specific conditions.

As the major signal in the top-down pathway, mTOR drives a phosphorylation cascade that ends in the activation of key transcription factors, such as c-Myc, sterol regulatory element binding proteins (SREPBs) and hypoxia inducible factor 1 alpha (HIF1), through which mTOR prompts lipid biosynthesis and glucose metabolism [39]. Besides these metabolic players, mTOR directly and indirectly controls a wide array of transcription factors that are involved in $\mathrm{T}$ cell development, activation, polarization or differentiation, such as Nuclear Factor-kB (NF-kB,) Forkhead box O (FOXO), and Signal Transducer and Activator of Transcription (STAT) families [40]. This implies that the metabolic activation of T cells, driven by mTOR, translates in a complex transcriptional reprogramming.

Following TCR and CD28 engagement, c-Myc is induced and maintained through both transcriptional and post-transcriptional mechanisms, also supported by mTOR [39]. C-Myc is strictly required for cell growth and division: indeed, it induces a metabolic program based on the transcription of genes related to glucose catabolism, glutaminolysis and polyamine biosynthesis [41]. However, further layers of c-Myc signaling became apparent when the proteome and the phosphoproteome of activated T cells were analyzed: this study revealed the induction of certain c-Myc targets that were involved in ribosome biogenesis and translation initiation, thus pointing to post-transcriptional regulation by c-Myc of T cell activation [42].

Sterol regulatory element binding proteins (SREPBs) are transcription factors that promote the expression of genes devoted to fatty acid and cholesterol biosynthesis. They are activated, in an mTOR-dependent fashion, in T cells that receive a mitogenic stimulus, and are responsible for the lipid anabolism required for T cell division [43]. Interestingly, SREPBs are sensitive to the intracellular sterol content and initiate their transcriptional program under conditions of sterol deprivation [44], thus they may integrate mitogenic signals with the context of nutrient availability along $\mathrm{T}$ cell activation.

Hypoxia inducible factor 1 alpha (HIF1 $\alpha$ ) is a transcription factor that senses low oxygen tension and translates this environmental message into the switch from oxidative to glycolytic metabolism [45]. Several key roles have been identified for HIF1 $\alpha$ in T cell functions: as an example, HIF1 $\alpha$ drives T helper 17 cell polarization at the expense of Treg conversion, and this event is mediated by its direct transcriptional induction of the IL-17 gene [46]. Notably, HIF1 $\alpha$-deficient T cells showed the marked repression of a series of metabolism-related genes, and especially those involved in glycolysis [47].

Several metabolites can affect $\mathrm{T}$ cell functions in a bottom-up direction: for instance, the AMP / ATP ratio regulates Adenosine Monophosphate-activated Protein Kinase (AMPK) activity, some amino acids work as mTOR activators through several processes, and membrane phospholipids and cholesterol affect TCR signaling [2]. Some of these bottomup events can occur through transcriptional or post-transcriptional regulation. Indeed, there are several examples of metabolic enzymes that display "moonlighting" functions, in that they are employed in gene regulatory networks when not engaged in their metabolic cascade. Glyceraldehyde 3-phosphate dehydrogenase (GAPDH) catalyzes the sixth step of glycolysis; interestingly, it is one the most widely used among housekeeping genes or proteins in expression experiments. In several cell types, GAPDH has been shown to 
bind certain mRNAs and to repress translation; in T cells, this activity is exerted on the $3^{\prime}$ untranslated region (UTR) of Ifng mRNA, implying that when glycolysis is sustained, the IFN $\gamma$ protein can be translated, and that glycolysis and effector function are mechanistically linked through GAPDH [48]. Similarly, enolase 1, another enzyme of the glycolytic cascade, controls the transcription of certain splicing variants of the human FOXP3 gene, when it is not engaged in glycolysis [49].

Another level of the bottom-up regulation exerted by metabolic signals is the epigenetic remodeling. Indeed, the extent of histone and DNA acetylation and methylation can be profoundly affected by the availability of their substrates, namely acetyl and methyl groups. The citrate produced during the TCA cycle is exported through specific carriers from mitochondria to cytosol, where the enzyme ATP citrate lyase regenerates Acetyl-CoA, a major donor of acetyl groups for histone acetylation. In T helper 1 cells, this metabolic pathway is crucially required for histone acetylation and the transcription of genes related to effector function such as IFN $\gamma$ [50]. Other intermediates of the TCA cycle can affect methylation, acting as cofactors or inhibitors of specific demethylases. In Tregs, the genetic deficiency of mitochondrial complex III leads to a complete loss of Treg functions, in association with increased DNA methylation and with higher levels of 2-hydroxyglutarate and succinate, two metabolites with the known ability to suppress DNA demethylases [22]. Metabolic and epigenetic remodeling are tightly linked in the establishment of T cell exhaustion [27]; as an example, glutamine blockade rescues anti-tumor $\mathrm{T}$ cell effector functions while promoting the replenishment of the TCA cycle [51], which provides intermediates with the ability to modulate demethylase activity.

\section{RNA Flow Cytometry: Pros and Cons Compared to Other Techniques}

By virtue of the tight crosstalk between metabolism and transcriptional/post-transcriptional regulation, a quantitative analysis of gene and/or protein expression may provide relevant information on the activation of specific metabolic pathways. In line with this idea, Ahl et al. have recently developed a flow cytometry-based metabolic profiling of human leukocytes, named Met-Flow, which relies on the intracellular staining and multiparameter analysis of several key and rate-limiting metabolic proteins [52]. This approach allowed one to estimate which metabolic pathways were dominant among different leukocyte subtypes, or after in vitro activation, or following selective pharmacological inhibition. For the first time, flow cytometry allowed one to dissect major metabolic pathways in a heterogeneous population at the single-cell level and at the protein level. However, the lack of reliable antibodies covering the majority of intracellular enzymes, and the combination with intranuclear markers that may be required to identify certain cell types, may hinder the expansion of this method.

As compared to proteins, nucleic acids show a simpler molecular structure that renders the design of detection probes very straightforward. Indeed, at least theoretically, a specific gene locus or RNA molecules of a known sequence can be detected by one or more complementary probes. The gene expression dynamics underlying $\mathrm{T}$ cell metabolism render RNA analysis an essential tool for immunological studies in the field. Standard methods for RNA analysis currently include quantitative and real-time PCR, expression microarrays and RNA sequencing for the transcriptome analysis [53]. These techniques show high sensitivity, are suitable for high-throughput experiments and allow populationor single cell-restricted analysis upon sample sorting and represent a gold standard for accurate RNA quantification. Immunological studies often involve experimental conditions with rare cell populations or limited sample amounts that render cell sorting impractical and sometimes not feasible. In the last decade, flow cytometry-based approaches have been developed that allow single-cell RNA detection from heterogeneous samples, that include the SmartFlare TM (EMD Millipore, Burlington, MA, USA) system and the Prime Flow TM (Thermo Fisher Scientific, Waltham, MA, USA). As compared to earlier detection attempts, such as the fluorescent in situ hybridization (FISH), these methods preserve better cells and fluorochromes properties, resulting in better sample quality. Moreover, unlike FISH and 
other microscopy based-methods, they are also feasible for non-adherent cells staining and allow high-throughput multiparametric screening because RNA detection can be carried out in association with phenotypical analysis [54,55].

The SmartFlare technology takes advantage of a three-component system, where oligonucleotides complementary to a specific RNA are conjugated to gold nanoparticles and bound to a fluorescent-tagged reporter (Figure 1). The conjugate is internalized into the cytoplasm and the RNA of interest, if present inside the cell, will displace the lower affinity fluorescently tagged reporter from the complementary oligonucleotide. Consequently, the reporter oligonucleotide is no longer quenched, and the emitted fluorescence can be detected by a flow cytometer. Although the SmartFlare ${ }^{\mathrm{TM}}$ does not affect cell viability and is thus feasible for downstream experiments, it has not met a broad application for multiparametric immunological studies and the limited availability of fluorophores (only Cy3 and Cy5) is probably among the reasons. Nevertheless, the technology has proven useful for the characterization of tumor cell lines, screening the efficacy of new drugs [56] and in the identification of pluripotent stem cells in different mammalian tissues [57].
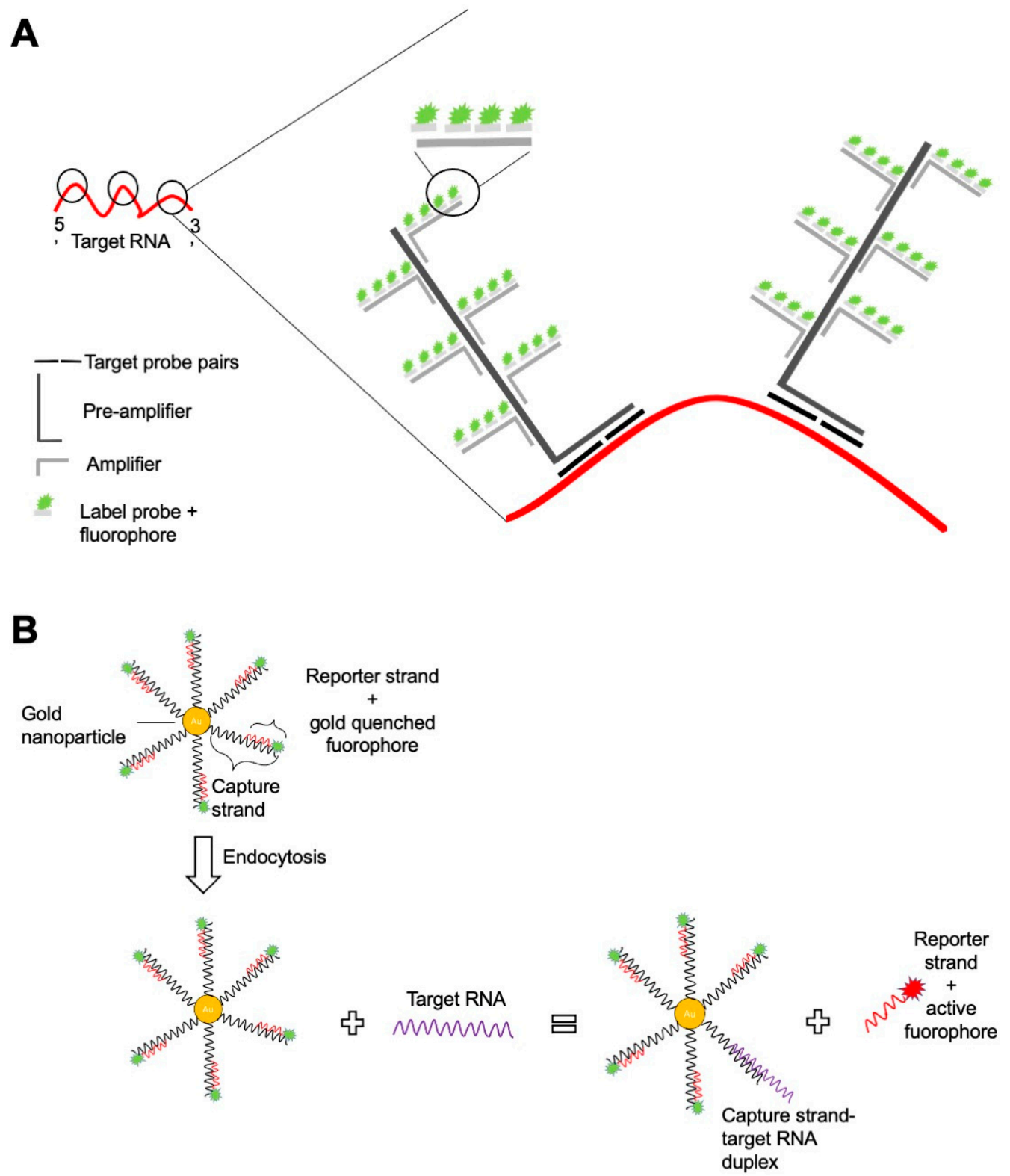

Figure 1. Scheme of the branched-DNA chemistry applied in the Prime Flow ${ }^{\mathrm{TM}}$ protocol (A) and of the SmartFlare chemistry (B). 
The multiparametric setting of immunological studies, especially those focused on metabolism, have taken much advantage of RNA analysis based on the branched DNA technology, namely Prime Flow ${ }^{\mathrm{TM}}$ and the strictly related FISH-flow (Table 1). Prime Flow ${ }^{\mathrm{TM}}$ allows for the simultaneous detection of up to four target RNA of different types (mRNA, microRNA, viral and long non-coding RNA) in combination with surface and intracellular/intranuclear staining. In the assay workflow, cells that have been previously stained with antibodies specific to surface molecules are fixed and permeabilized using a proprietary buffer that preserves RNA transcripts. Subsequently, a hybridization step is performed with oligonucleotide pairs, or target probes (TBs), that hybridize on complementary sequences on the target RNA (Figure 1). Each batch contains 20-40 TB pairs (or a single pair in the case of miRNA probe sets) to allow both for specificity and for signal amplification. Indeed, only if all the TB pairs hybridize adjacent to each other the subsequent recognition by pre-amplifier and amplifier oligonucleotides can occur. After the amplification steps, oligonucleotides conjugated to fluorochromes (label probes) are added to hybridize with multiple sites on the amplifiers. An optimally assembled branched DNA complex can provide a theoretical 8000 - to 16,000 -fold signal amplification of the targeted RNA [54].

Table 1. RNA and protein analysis by flow cytometry.

\begin{tabular}{|c|c|c|c|c|}
\hline Technique & Molecular Target & Platform & Application & Refs \\
\hline Met-Flow & Proteins & $\begin{array}{l}\text { Flow cytometry: BD X-30 } \\
\text { FACSymphony ( } 27 \text { colors })\end{array}$ & $\begin{array}{l}\text { Characterization metabolic pathways in } \\
\text { immune cells }\end{array}$ & [52] \\
\hline SmartFlare & RNA & $\begin{array}{l}\text { Flow cytometry } \\
\text { Fluorescence plate reader }\end{array}$ & $\begin{array}{l}\text { Studying gene expression in live cells } \\
\text { for downstream application }\end{array}$ & [56-61] \\
\hline \multirow{4}{*}{$\begin{array}{l}\text { PrimeFlow } \\
\text { FISH-Flow }\end{array}$} & \multirow{4}{*}{ RNA } & \multirow{4}{*}{$\begin{array}{l}\text { Flow cytometry: } \\
\text { BD LSR Fortessa (13 } \\
\text { colors), BD LSR II ( } 2 \text { to } \\
11 \text { colors), Beckman } \\
\text { Coulter Gallios } \\
\text { (6 to } 10 \text { colors) }\end{array}$} & $\begin{array}{l}\text { Analyze mRNA expression at the } \\
\text { single-cell level }\end{array}$ & [62-83] \\
\hline & & & $\begin{array}{l}\text { Analyze RNA and protein kinetics in } \\
\text { the same cell }\end{array}$ & [84-104] \\
\hline & & & Detection of viral RNA in infected cells & {$[105-114]$} \\
\hline & & & Detect microRNA (miRNA) & {$[90,115-120]$} \\
\hline
\end{tabular}

The different types of RNA detectable by Prime Flow result in a broad range of applications that are summarized in Table 1. The simultaneous detection of RNAs and their cognate proteins allow one to study their dynamics in specific cell populations. For instance, the combination of Tumor Necrosis Factor (TNF) $\alpha$ mRNA and cognate protein detection in lipopolysaccharide (LPS)-stimulated macrophages at different time points has been used to identify the length of incubation needed to initiate protein translation [103]. Posttranscriptional regulation can be more finely studied in specific cell types by combining protein expression and/or mRNA with the detection of microRNA. Lai and coworkers unveiled unique microRNA profiles in the four peritoneal cell subsets of murine macrophages by combining microRNA, mRNA and protein detection [118].

RNA flow cytometry also offers an alternative detection tool when the measurement of a protein is technically infeasible either because no quality antibody exists, or the epitope is not accessible [54]. We have used Prime Flow TM to study genes involved in fatty acid metabolism (Pparg, Acacb, and Cpt1a) in intratumoral conventional CD4 T cells and Tregs [83]. Besides overcoming the antibody availability, we were able to perform the analysis on single tumors, thus taking into account sample heterogeneity. Indeed, the isolation of tumor-infiltrating lymphocytes by single cell sorting in mice is often performed on pools of several samples to achieve cell numbers adequate for gene or protein expression analysis, but to the disadvantage of accuracy. Another noticeable application of FISH-flow has been the identification of latent HIV infection in peripheral blood cells. The combined staining with Gagpol mRNA and the Gag protein allowed the identification of virus infected 
CD4+ T cells in patients undergoing antiretroviral therapy with a detection limit of Gagpol $\mathrm{mRNA}+/$ Gag protein + cells per million CD4+ T cells [110].

\section{An Example of Combined Detection of RNA, Nuclear Factors and Mitochondria by Flow Cytometry}

In the latest years, the interest in defining a complete profile of tumor-infiltrating immune cells by a phenotypic, transcriptional and metabolic point of view has become noticeable, especially considering the impact of "immune contexture" in modulating cancer progression and in determining patient prognosis [121]. A substantial field of study focused on the characterization of Tregs in the cancer microenvironment, since these cells are thought to be a major barrier to therapeutic efforts to mobilize the immune system against the tumor [122]. The possibility of identifying unique characteristics that could distinguish tumor-infiltrating Tregs from other Tregs in the body, as well as from the beneficial anti-tumor effector $\mathrm{T}$ cells within tumors, could be exploited to target or to reprogram tumor Tregs for cancer treatment [123]. A good knowledge about Tregs has been achieved regarding specific aspects: (i) the existence of a transcriptional signature has been highlighted, specifically associated with Tregs in thousands of tumors from different stages and locations and conserved across species [124]; (ii) the expression of a miRNA in a subset of tumor Tregs has been reported to regulate their proliferation and immunosuppressive capacity [125]; (iii) many metabolic peculiarities have been associated to specific biological aspects of Tregs in tumor microenvironment [20], and in this context, a key role for Treg suppressive function has been attributed to molecules that regulate mitochondrial integrity and function [25].

The technical ability to recognize and intersect as many features as possible, and to simultaneously compare different kinds of data (including RNA expression and metabolic traits) from several cell populations interacting in the same heterogeneous tissue, such as a tumor, could be crucial to highlight differences potentially useful for focused therapeutic intervention. Several examples can be found in the literature of the usage of the Prime Flow technique to analyze $\mathrm{T}$ cells in complex samples. Thanks to this approach, we had the possibility to associate the phenotypic profile of tumor-infiltrating lymphocytes (TILs) to the expression of key genes of specific metabolic pathways, and these data were confirmed by a gene expression analysis [83]. Others could unveil the critical role of a stress-responsive transcription factor in the maintenance of TIL mitochondrial fitness and function by using the respective RNA-labelled probe and could discriminate a differential expression of this gene in phenotypically, functionally and metabolically different TIL subsets [126]. Another group identified the high expression of the adenosine receptor A2AR in central memory CD8 T cell subset through its mRNA probe detection: this receptor dictated the TIL susceptibility to adenosine-mediated suppression in the tumor microenvironment that impairs CD8 T cell metabolic fitness and cytokine production [69]. However, especially in the latest two works, the overall significance of the data resulted from the contribution of different analysis techniques and not only Prime Flow analysis.

Here, we describe a protocol that combines the identification of TIL phenotypical characteristics with RNA detection by Prime Flow assay and with the measurement of mitochondrial function by using a specific fixable dye, belonging to the MitoTracker family dyes, named MitoTracker Deep Red (MDR). This protocol allows one to evaluate all these aspects in Tregs and CD4+ conventional T cells (Tconvs) in the same sample by flow cytometry. The subcutaneous-implanted colon carcinoma cell line MCA38 was used as a tumor model. TILs were enriched through a 40/80 Percoll density gradient from tumor samples, while splenocytes were used as the control. The staining protocol is outlined in the workflow in Figure 2. 


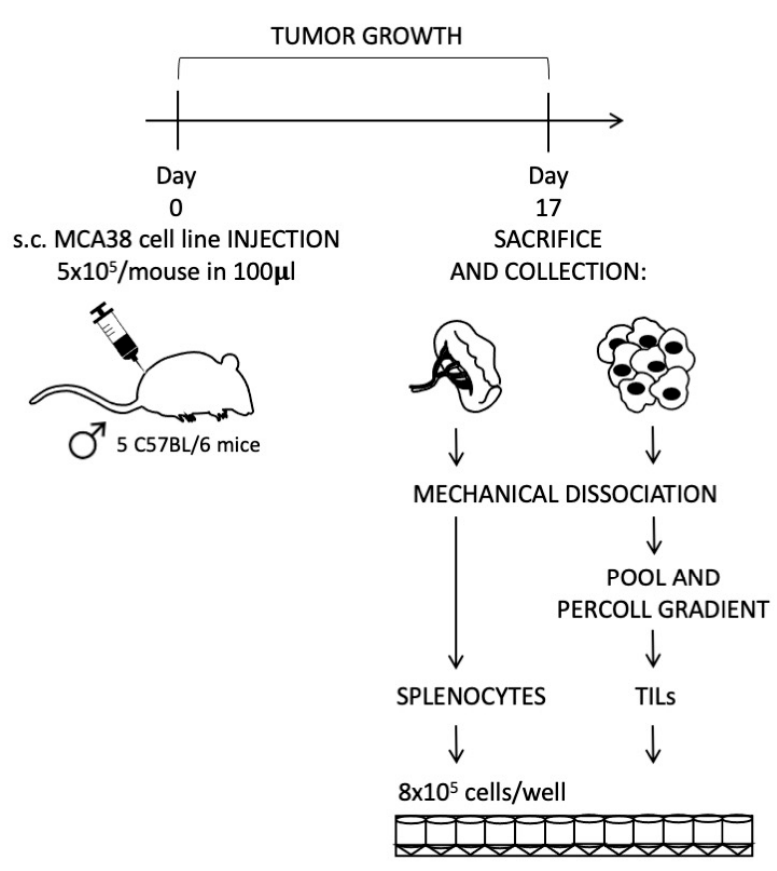

\begin{tabular}{|c|c|c|c|}
\hline 1 & \multicolumn{3}{|c|}{$\begin{array}{l}\text { Viability dye } 1: 1000 \text { in PBS } \\
30 \text { min RT }\end{array}$} \\
\hline 2 & \multicolumn{3}{|c|}{$\begin{array}{l}\text { Surface staining in PBS } 2 \% \mathrm{FBS} \text { : } \\
20 \mathrm{~min} \text { at } 4^{\circ} \mathrm{C}\end{array}$} \\
\hline & CD71 BV421 & 1:50 & \\
\hline & CD44 BV510 & 1:50 & \\
\hline & OX40 BV605 & 1:50 & \\
\hline & CD4 BV785 & 1:50 & \\
\hline 3 & \multicolumn{3}{|l|}{$\begin{array}{l}\text { MDR loading in PBS: } \\
100 \mathrm{nM} 30 \mathrm{~min} \text { at } 37^{\circ} \mathrm{C}\end{array}$} \\
\hline 4 & \multicolumn{3}{|c|}{$\begin{array}{l}1^{\circ} \text { Fixation step: } \\
\text { Fixation Buffer } 1 \text { (Fixation Buffer } 1 \mathrm{~A}+\text { Fixation Buffer 1B, 1:1) } \\
30 \mathrm{~min} \text { at } 4^{\circ} \mathrm{C}\end{array}$} \\
\hline 5 & \multicolumn{3}{|c|}{$\begin{array}{l}\text { Permeabilization: } \\
2 \text { washes } 1000 \text { x } 4 \text { min with } 1 X \text { Permeabilization Buffer + RNase Inhibitors }\end{array}$} \\
\hline \multirow[t]{3}{*}{6} & \multicolumn{3}{|c|}{$\begin{array}{l}\text { Intracellular staining in } 1 X \text { Permeabilization Buffer + RNase Inhibitors: } \\
1 \mathrm{~h} \mathrm{RT}\end{array}$} \\
\hline & Foxp3 PE-eFluor 610 & $1: 50$ & \\
\hline & Ki67 PE-cy7 & 1:50 & \\
\hline 7 & \multicolumn{3}{|c|}{$\begin{array}{l}2^{\circ} \text { Fixation step: } \\
1 \mathrm{X} \text { Fixation Buffer } 2 \\
1 \mathrm{~h} \mathrm{RT} \text { or overnight at } 4^{\circ} \mathrm{C}\end{array}$} \\
\hline 8 & \multicolumn{3}{|c|}{$\begin{array}{l}\text { Target probe hybridization: } \\
\boldsymbol{\beta} \text {-Actin probes } 1: 20 \text { in Target probe diluent + wash buffer (1:1) } \\
1 \mathrm{~h} \text { at } 40^{\circ} \mathrm{C}\end{array}$} \\
\hline 9 & $\begin{array}{l}\text { Signal amplification } \\
\text { - PreAmp Mix + was } \\
\text { - Amp Mix + wash b } \\
\text { - Label Probe 1:100 }\end{array}$ & $\begin{array}{l}\text { sequential hybridization steps: } \\
\text { buffer (1:1) } \\
\text { ffer (1:1) } \\
\text { l Label Probe Diluent + wash buffer (1:1) } 1\end{array}$ & $\begin{array}{l}1,5 \text { h at } 40^{\circ} \mathrm{C} \\
1,5 \text { h at } 40^{\circ} \mathrm{C} \\
1 \text { h at } 40^{\circ} \mathrm{C}\end{array}$ \\
\hline 10 & Flow cytometry ar & ith LSR For & \\
\hline
\end{tabular}

Figure 2. Workflow of the combined staining of surface and nuclear markers, mitochondria and specific mRNAs. PBS, phosphate buffered saline.

In more detail, at first cells were incubated with the fixable viability dye (APCeFluor780) to allow for the detection and exclusion of dead cells, and then the staining for surface antigens was performed by using the following antibodies: CD4 (Brilliant Violet 785) for cell lineage identification, CD44 (Brilliant Violet 510) as activation marker, OX40 (Brilliant Violet 605), a member of TNF-receptor superfamily highly expressed in tumor Tregs and CD71 (Brilliant Violet 421), the transferrin receptor. The latter two markers were analyzed based on data in the literature and data from our laboratory: genes encoding for OX40 and CD71 belong to a conserved tumor-specific Treg signature that has been identified in a meta-analysis by Zheng et al. [127]; moreover, we demonstrated that OX40 expression is distinctive of a proliferating, stable and highly suppressive activated Treg subset in tumor tissue [128,129].

After surface staining, cells were incubated with MDR, a carbocyanine-based and far red-fluorescent dye (absorption/emission $\sim 644 / 665 \mathrm{~nm}$ ), that passively diffuses across the plasma membrane and stains mitochondria in live cells, allowing for the quantification of the active mitochondrial mass [130]. Different cell-permeant MitoTracker probes for mitochondria labelling exist which differ in spectral characteristics, fixability and fluorescence mechanism. In this experimental setting, MDR was chosen because it is retained during cell permeabilization and fixation (required for intracellular staining and Prime Flow assay) and it is suited for multicolor labelling experiments.

Then, we started the Prime Flow protocol: cells underwent the first of two fixation steps, in order to warrant the immobilization and stability of the surface and intracellular antigens, as well as the mitochondrial labelling and target RNA. After this fixation step, cells were permeabilized by two washings with a permeabilization buffer containing RNase inhibitors, in order to preserve the integrity of mRNA transcripts, and then intracellular 
staining for Foxp3 (PE-eFluor610), the master regulator gene of Tregs, and Ki67 (PE-Cy7), a nuclear marker of cell proliferation, was performed.

At this point, cells underwent the second fixation step, followed by the first hybridization step, which allows for the annealing of mRNA-specific oligonucleotide "target probe" to the RNA sequence of interest, $\beta$-Actin in our case. Beta-actin is generally used as a housekeeping gene in several techniques. After the specific mRNA targeting, sequential hybridization steps were performed, based on branched DNA chemistry, in order to increase the specificity of the detection system and to greatly amplify the signal of annealed target probes. At the end of the procedure, labelled samples were acquired on a cell analyzer and were analyzed with appropriate software.

As a result of this optimized protocol, we had the opportunity to measure the expression of transcripts ( $\beta$-Actin) together with surface and nuclear antigens at the single cell level, in combination with a dye that gave us information about the cell metabolic status. Interestingly, we could compare all these aspects, simultaneously, in distinct cell populations that inhabit the same heterogeneous tissue. This analysis allowed one to unveil that, compared to Tconvs, and to Tregs from spleen, tumor-infiltrating Tregs expressed a higher level of activation markers (CD44, CD71 and OX40), proliferated at a higher extent (as indicated by the higher Ki67 expression) and showed an increased mitochondrial mass (as revealed by MDR staining). As expected, all the cells expressed high levels of $\beta$-Actin mRNA (Figure 3).

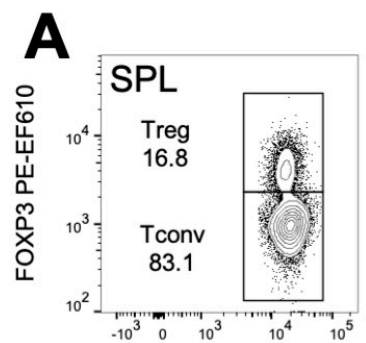

CD4 BV785

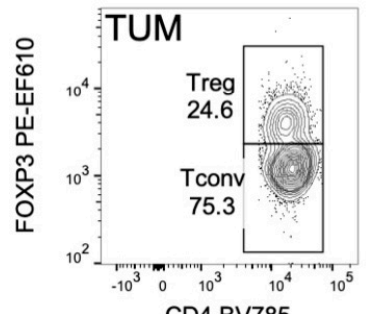

CD4 BV785
B

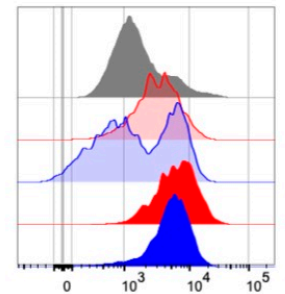
CD44 BV510 \begin{tabular}{|l|l|l|}
\hline SPL & CD4- & 1572 \\
\hline
\end{tabular} \begin{tabular}{|l|l|l|}
\hline SPL & CD4- & 1572 \\
\hline SPL & Treg & 2898 \\
\hline
\end{tabular} \begin{tabular}{|l|l|l|}
\hline SPL & Tconv & 1502 \\
\hline TUM & Treg & 5789 \\
\hline
\end{tabular} \begin{tabular}{ll|l}
\hline TUM & Treg & 5789 \\
\hline
\end{tabular}

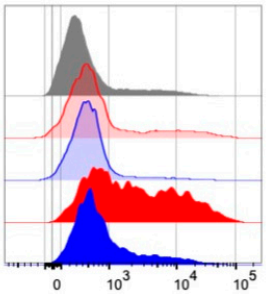
Ki67 PE-CY7 \begin{tabular}{|l|l|l|}
\hline SPL & CD4- & 501 \\
\hline
\end{tabular} \begin{tabular}{lll}
\hline SPL & Treg 781 \\
\hline
\end{tabular} 口 SPL Tconv 549 IUM Treg 2147 \begin{tabular}{ll} 
- TUM Tconv 846 \\
\hline
\end{tabular}

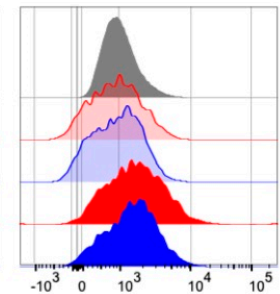

CD71 BV421

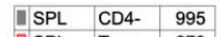
\begin{tabular}{|l|l|r|}
\hline SPL & Treg & 873 \\
\hline
\end{tabular} \begin{tabular}{|l|r|r|}
\hline ] SPL & Tconv & 892 \\
\hline
\end{tabular} \begin{tabular}{|l|l|l|}
\hline TUM & Trenv & 1413 \\
\hline
\end{tabular}

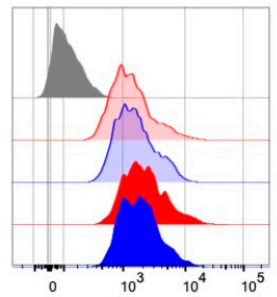

MDR

\begin{tabular}{|l|l|l|}
\hline IFMO & CD4 & 123 \\
\hline
\end{tabular}

\begin{tabular}{ll|r|}
\hline SPL & Treg 1318 \\
\hline
\end{tabular}

口 SPL Tconv 1513

- TUM Treg 2120

- TUM Tconv 1770

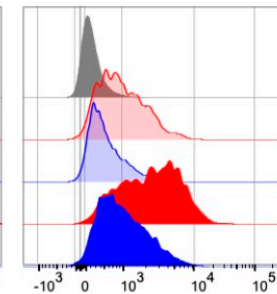

OX40 BV605

\begin{tabular}{|l|l|l|}
\hline SPL & CD4- & 221 \\
\hline
\end{tabular} [ SPL Treg 952 SUL Tconv 540 TUM Tconv 2257

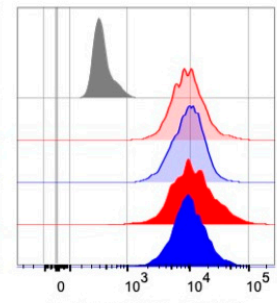

Actb mRNA AF488

\begin{tabular}{|l|l|r|}
\hline FMO & CD4 & 435 \\
\hline
\end{tabular}

\begin{tabular}{ll|l|}
\hline SPL & Treg 8937 \\
\hline
\end{tabular}

SPL Tconv 8855

TUM Treg 10808

- TUM Tconv 9172

Figure 3. Detection of $\beta$-Actin mRNA in combination with surface and nuclear proteins and with mitochondrial mass in Tregs and Tconvs from splenocytes (SPL) and tumor tissue (TUM) by flow cytometry. MC 38 cells $\left(5 \times 10^{5}\right)$ were subcutaneously injected into C57BL/6 mice and Prime Flow assay and flow cytometry analysis were performed on lymphocytes extracted from splenocytes and tumor tissue at 17 days post-tumor transplantation. Staining was performed according to the workflow in Figure 2. (A) Contour plots showing the strategy for the identification of Tregs and Tconvs in SPL and TUM, according to Foxp3 intranuclear expression. (B) Overlay of the histograms showing the expression of each marker in the indicated cell subset and tissue. Numbers in the legends indicate the geometric mean fluorescence intensity (gMFI). Grey histograms represent the fluorescence-minus-one (FMO) negative controls or CD4-negative cells, as control. 
These results confirm previous data [83] indicating that tumor-infiltrating Tregs have a profile that is compatible with functional and metabolic activation. Indeed, compared to spleen-Tregs and to Tconvs, they express very high levels of OX40 and also contain a relevant proportion of proliferating cells. This is in line with previous studies showing a proliferative role of OX40 on Tregs [131]. This phenotype was not associated with a significant increase in mitochondrial mass, as revealed by MDR staining. Others have shown that, in a different tumor model, tumor-infiltrating Tregs contain a lower mitochondrial mass compared to spleen Tregs [25]: it is thus possible that mitochondrial biogenesis is not required for the activation and functions of Tregs at the tumor site.

The multiparameter flow cytometry data obtained from this type of experiment were suitable for multidimensionality reduction and clustering analysis using bioinformatic tools such as t-distributed Stochastic Neighbor Embedding (tSNE) and/or Uniform Manifold Approximation and Projection (UMAP) (Figure 4). To perform this analysis, CD4 T cells from spleen and tumors were gated, downsampled and concatenated together, then, Tregs and Tconvs were manually identified based on Foxp3 expression (Figure 4A). Both UMAP and tSNE analyses displayed that Tregs and Tconvs from tumors and spleens populated distinct areas in the bidimensional plots (Figure 4B). Interestingly, the visualization of marker coexpression highlighted that proliferating (Ki67+) cells tended to display distinctive features (Figure 4C). Interestingly, proliferating cells were characterized by higher levels of $\beta$-Actin mRNA expression: this observation suggests that $\beta$-Actin analysis may not only be useful as a positive control for the RNA flow assay but also give potential information on T cell activation. Indeed, TCR-dependent reorganization of the actin cytoskeleton is a key event in the formation of the immunological synapse and in cell motility [132], and our data suggest that the control of $\beta$-Actin activity may also be exerted at the transcriptional level in proliferating cells.
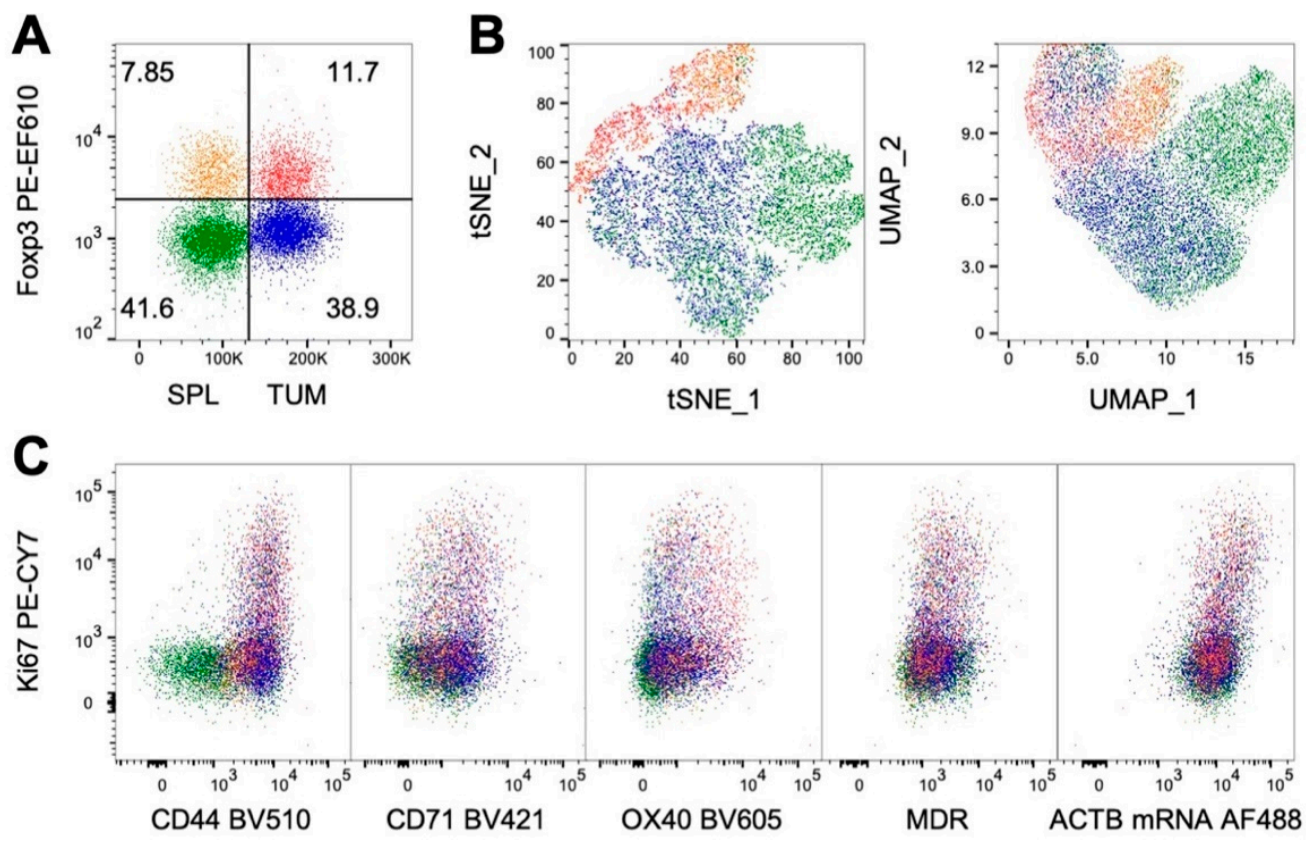

Figure 4. Unsupervised clustering analysis of flow cytometry data obtained from Tregs and Tconvs from spleen (SPL) or tumors (TUM). Gated CD4 T cells were downsampled and concatenated together and Tregs and Tconvs in both samples were manually identified according to Foxp3 expression. (A) Plot showing the overlay of gated Tregs and Tconvs in concatenated CD4 T cells from SPL and TUM. (B) tSNE (left) and UMAP (right) visualization of the distribution of Treg and Tconv populations from SPL and TUM in the concatenated samples according to the expression of markers indicated in Figure 3. Both multidimensionality reduction analyses were run with default settings in Flowjo 10.5.3. (C) Representation of the co-expression of Ki67 with the other markers in overlayed Treg and Tconv subsets in concatenated CD4 T cells from SPL e TUM samples. 


\section{Conclusions}

Metabolic switches are key events and dictate the outcome of $\mathrm{T}$ cell activation, thus their characterization is of utmost importance in understanding the $\mathrm{T}$ cell response to microenvironmental signals and nutrients. Studying gene expression can provide significant information on the main metabolic pathways that are active in specific cell types and states. Recent advances in flow cytometry allow for the simultaneous analysis of specific mRNAs and metabolic, phenotypic and functional markers in complex populations, with unprecedented resolution. This approach may be instrumental in studying how $\mathrm{T}$ cells adapt their metabolism and thus their functions to cope with metabolic restriction in certain tissue microenvironments, such as the tumor site.

Besides contributing to produce high quality data for basic research, this approach also has potential clinical relevance. For instance, the reactivation of effector T cells in cancer patients undergoing immunotherapy with immune checkpoint inhibitors relies on the modulation of metabolic pathways in exhausted cells [27]. In this view, monitoring the metabolic status of effector lymphocytes in these patients might be useful to assess their response to therapy in real time. Indeed, RNA flow cytometry can be performed on samples of limited size (e.g., peripheral blood leucocytes from routine blood tests) as compared to classical metabolic assays ex vivo and in a relatively short time. Moreover, as we discussed in the text, the study of metabolism can be performed in parallel with phenotypical and miRNA analysis that allows for correlations with activation, proliferative status of cells and possibly post-transcriptional regulation. Another potential clinical application we envisage for RNA flow includes the identification of rare viral reservoirs in patients chronically infected with HIV as well as other potentially harmful pathogens.

Funding: This manuscript was funded by AIRC (Associazione Italiana per la Ricerca sul Cancro), grant number IG-19784, and by the Italian Ministry of University and Research-PRIN, grant number 2017K7FSYB.

Acknowledgments: The authors would like to acknowledge Marta Zagaglioni, Gloria Tucci, Alessandra Pinzon Grimaldos and Federica Pelliccia for technical support.

Conflicts of Interest: The authors declare no conflict of interest.

\section{References}

1. O'Neill, L.A.; Kishton, R.J; Rathmell, J. A guide to immunometabolism for immunologists. Nat. Rev. Immunol. 2016, 16, 553-565. [CrossRef] [PubMed]

2. Shyer, J.A.; Flavell, R.A.; Bailis, W. Metabolic signaling in T cells. Cell Res. 2020, 30, 649-659. [CrossRef] [PubMed]

3. Pearce, E.L.; Poffenberger, M.C.; Chang, C.H.; Jones, R.G. Fueling immunity: Insights into metabolism and lymphocyte function. Science 2013, 342, 1242454. [CrossRef] [PubMed]

4. Van der Windt, G.J.; O'Sullivan, D.; Everts, B.; Huang, S.C.; Buck, M.D.; Curtis, J.D.; Chang, C.H.; Smith, A.M.; Ai, T.; Faubert, B.; et al. CD8 memory T cells have a bioenergetic advantage that underlies their rapid recall ability. Proc. Natl. Acad. Sci. USA 2013, 110, 14336-14341. [CrossRef] [PubMed]

5. Frauwirth, K.A.; Riley, J.L.; Harris, M.H.; Parry, R.V.; Rathmell, J.C.; Plas, D.R.; Elstrom, R.L.; June, C.H.; Thompson, C.B. The CD28 signaling pathway regulates glucose metabolism. Immunity 2002, 16, 769-777. [CrossRef]

6. Macintyre, A.N.; Gerriets, V.A.; Nichols, A.G.; Michalek, R.D.; Rudolph, M.C.; Deoliveira, D.; Anderson, S.M.; Abel, E.D.; Chen, B.J.; Hale, L.P.; et al. The glucose transporter Glut1 is selectively essential for CD4 T cell activation and effector function. Cell Metab. 2014, 20, 61-72. [CrossRef] [PubMed]

7. Jacobs, S.R.; Herman, C.E.; Maciver, N.J.; Wofford, J.A.; Wieman, H.L.; Hammen, J.J.; Rathmell, J.C. Glucose uptake is limiting in T cell activation and requires CD28-mediated Akt-dependent and independent pathways. J. Immunol. 2008, 180, 4476-4486. [CrossRef]

8. Patsoukis, N.; Bardhan, K.; Chatterjee, P.; Sari, D.; Liu, B.; Bell, L.N.; Karoly, E.D.; Freeman, G.J.; Petkova, V.; Seth, P.; et al. PD-1 alters T-cell metabolic reprogramming by inhibiting glycolysis and promoting lipolysis and fatty acid oxidation. Nat. Commun. 2015, 6, 6692. [CrossRef]

9. Geltink, R.I.K.; O'Sullivan, D.; Corrado, M.; Bremser, A.; Buck, M.D.; Buescher, J.M.; Firat, E.; Zhu, X.; Niedermann, G.; Caputa, G.; et al. Mitochondrial priming by CD28. Cell 2017, 171, 385-397. [CrossRef]

10. Buck, M.D.; O'Sullivan, D.; Geltink, R.I.K.; Curtis, J.D.; Chang, C.H.; Sanin, D.E.; Qiu, J.; Kretz, O.; Braas, D.; van der Windt, G.J.; et al. Mitochondrial dynamics controls T cell fate through metabolic programming. Cell 2016, 166, 63-76. [CrossRef] 
11. Corrado, M.; Edwards-Hicks, J.; Villa, M.; Flachsmann, L.J.; Sanin, D.E.; Jacobs, M.; Baixauli, F.; Stanczak, M.; Anderson, E.; Azuma, M.; et al. Dynamic cardiolipin synthesis is required for CD8(+) T cell immunity. Cell Metab. 2020, 32, 981-995. [CrossRef] [PubMed]

12. Takahashi, T.; Kuniyasu, Y.; Toda, M.; Sakaguchi, N.; Itoh, M.; Iwata, M.; Shimizu, J.; Sakaguchi, S. Immunologic self-tolerance maintained by CD25+CD4+ naturally anergic and suppressive T cells: Induction of autoimmune disease by breaking their anergic/suppressive state. Int. Immunol. 1998, 10, 1969-1980. [CrossRef] [PubMed]

13. Yang, S.; Fujikado, N.; Kolodin, D.; Benoist, C.; Mathis, D. Immune tolerance. Regulatory T cells generated early in life play a distinct role in maintaining self-tolerance. Science 2015, 348, 589-594. [CrossRef] [PubMed]

14. Tuncel, J.; Benoist, C.; Mathis, D. T cell anergy in perinatal mice is promoted by T reg cells and prevented by IL-33. J. Exp. Med. 2019, 216, 1328-1344. [CrossRef] [PubMed]

15. Burzyn, D.; Benoist, C.; Mathis, D. Regulatory T cells in nonlymphoid tissues. Nat. Immunol. 2013, 14, 1007-1013. [CrossRef]

16. Piconese, S.; Cammarata, I.; Barnaba, V. Viral hepatitis, inflammation, and cancer: A lesson for autoimmunity. J. Autoimmun. 2018, 95, 58-68. [CrossRef] [PubMed]

17. Michalek, R.D.; Gerriets, V.A.; Jacobs, S.R.; Macintyre, A.N.; MacIver, N.J.; Mason, E.F.; Sullivan, S.A.; Nichols, A.G.; Rathmell, J.C. Cutting edge: Distinct glycolytic and lipid oxidative metabolic programs are essential for effector and regulatory CD4+ T cell subsets. J. Immunol. 2011, 186, 3299-3303. [CrossRef]

18. Zeng, H.; Yang, K.; Cloer, C.; Neale, G.; Vogel, P.; Chi, H. mTORC1 couples immune signals and metabolic programming to establish T(reg)-cell function. Nature 2013, 499, 485-490. [CrossRef]

19. Chapman, N.M.; Zeng, H.; Nguyen, T.M.; Wang, Y.; Vogel, P.; Dhungana, Y.; Liu, X.; Neale, G.; Locasale, J.W.; Chi, H. mTOR coordinates transcriptional programs and mitochondrial metabolism of activated Treg subsets to protect tissue homeostasis. Nat. Commun. 2018, 9, 2095. [CrossRef] [PubMed]

20. Pacella, I.; Piconese, S. Immunometabolic checkpoints of treg dynamics: Adaptation to microenvironmental opportunities and challenges. Front. Immunol. 2019, 10, 1889. [CrossRef]

21. Kishore, M.; Cheung, K.C.P.; Fu, H.; Bonacina, F.; Wang, G.; Coe, D.; Ward, E.J.; Colamatteo, A.; Jangani, M.; Baragetti, A.; et al. Regulatory T cell migration is dependent on glucokinase-mediated glycolysis. Immunity 2017, 47, 875-889. [CrossRef] [PubMed]

22. Weinberg, S.E.; Singer, B.D.; Steinert, E.M.; Martinez, C.A.; Mehta, M.M.; Martinez-Reyes, I.; Gao, P.; Helmin, K.A.; AbdalaValencia, H.; Sena, L.A.; et al. Mitochondrial complex III is essential for suppressive function of regulatory T cells. Nature 2019, 565, 495-499. [CrossRef] [PubMed]

23. Angelin, A.; Gil-de-Gomez, L.; Dahiya, S.; Jiao, J.; Guo, L.; Levine, M.H.; Wang, Z.; Quinn, W.J., III; Kopinski, P.K.; Wang, L.; et al. Foxp3 Reprograms T Cell Metabolism to Function in Low-Glucose, High-Lactate Environments. Cell Metab. 2017, 25, 1282-1293. [CrossRef]

24. Beier, U.H.; Angelin, A.; Akimova, T.; Wang, L.; Liu, Y.; Xiao, H.; Koike, M.A.; Hancock, S.A.; Bhatti, T.R.; Han, R.; et al. Essential role of mitochondrial energy metabolism in Foxp3(+) T-regulatory cell function and allograft survival. FASEB J. 2015, 29, 2315-2326. [CrossRef]

25. Field, C.S.; Baixauli, F.; Kyle, R.L.; Puleston, D.J.; Cameron, A.M.; Sanin, D.E.; Hippen, K.L.; Loschi, M.; Thangavelu, G.; Corrado, M.; et al. Mitochondrial integrity regulated by lipid metabolism is a cell-intrinsic checkpoint for treg suppressive function. Cell Metab. 2020, 31, 422-437. [CrossRef] [PubMed]

26. Van der Windt, G.J.; Everts, B.; Chang, C.H.; Curtis, J.D.; Freitas, T.C.; Amiel, E.; Pearce, E.J.; Pearce, E.L. Mitochondrial respiratory capacity is a critical regulator of CD8+ T cell memory development. Immunity 2012, 36, 68-78. [CrossRef]

27. Franco, F.; Jaccard, A.; Romero, P.; Yu, Y.R.; Ho, P.C. Metabolic and epigenetic regulation of T-cell exhaustion. Nat. Metab. 2020, 2, 1001-1012. [CrossRef]

28. Scharping, N.E.; Menk, A.V.; Moreci, R.S.; Whetstone, R.D.; Dadey, R.E.; Watkins, S.C.; Ferris, R.L.; Delgoffe, G.M. The tumor microenvironment represses $\mathrm{T}$ cell mitochondrial biogenesis to drive intratumoral $\mathrm{T}$ cell metabolic insufficiency and dysfunction. Immunity 2016, 45, 374-388. [CrossRef]

29. Yu, Y.R.; Imrichova, H.; Wang, H.; Chao, T.; Xiao, Z.; Gao, M.; Rincon-Restrepo, M.; Franco, F.; Genolet, R.; Cheng, W.C.; et al. Disturbed mitochondrial dynamics in CD8(+) TILs reinforce T cell exhaustion. Nat. Immunol. 2020, 21, 1540-1551. [CrossRef]

30. Simula, L.; Pacella, I.; Colamatteo, A.; Procaccini, C.; Cancila, V.; Bordi, M.; Tregnago, C.; Corrado, M.; Pigazzi, M.; Barnaba, V.; et al. Drp1 controls effective T cell immune-surveillance by regulating T cell migration, proliferation, and CMYC-dependent metabolic reprogramming. Cell Rep. 2018, 25, 3059-3073. [CrossRef]

31. Li, Y.H.; Xu, F.; Thome, R.; Guo, M.F.; Sun, M.L.; Song, G.B.; Li, R.L.; Chai, Z.; Ciric, B.; Rostami, A.M.; et al. Mdivi-1, a mitochondrial fission inhibitor, modulates $\mathrm{T}$ helper cells and suppresses the development of experimental autoimmune encephalomyelitis. J. Neuroinflamm. 2019, 16, 149. [CrossRef]

32. Manzo, T.; Prentice, B.M.; Anderson, K.G.; Raman, A.; Schalck, A.; Codreanu, G.S.; Lauson, C.B.N.; Tiberti, S.; Raimondi, A.; Jones, M.A.; et al. Accumulation of long-chain fatty acids in the tumor microenvironment drives dysfunction in intrapancreatic CD8+ T cells. J. Exp. Med. 2020, 217, e20191920. [CrossRef] [PubMed]

33. Wang, H.; Franco, F.; Tsui, Y.C.; Xie, X.; Trefny, M.P.; Zappasodi, R.; Mohmood, S.R.; Fernandez-Garcia, J.; Tsai, C.H.; Schulze, I.; et al. CD36-mediated metabolic adaptation supports regulatory T cell survival and function in tumors. Nat. Immunol. 2020, 21, 298-308. [CrossRef] 
34. Ringel, A.E.; Drijvers, J.M.; Baker, G.J.; Catozzi, A.; Garcia-Canaveras, J.C.; Gassaway, B.M.; Miller, B.C.; Juneja, V.R.; Nguyen, T.H.; Joshi, S.; et al. Obesity shapes metabolism in the tumor microenvironment to suppress anti-tumor immunity. Cell 2020, 183, 1848-1866. [CrossRef] [PubMed]

35. Scharping, N.E.; Rivadeneira, D.B.; Menk, A.V.; Vignali, P.D.A.; Ford, B.R.; Rittenhouse, N.L.; Peralta, R.; Wang, Y.; Wang, Y.; DePeaux, K.; et al. Mitochondrial stress induced by continuous stimulation under hypoxia rapidly drives T cell exhaustion. Nat. Immunol. 2021, 22, 205-215. [CrossRef]

36. Nicholls, D.G. Mitochondrial membrane potential and aging. Aging Cell 2004, 3, 35-40. [CrossRef] [PubMed]

37. Dykens, J.A.; Will, Y. The significance of mitochondrial toxicity testing in drug development. Drug Discov. Today 2007, 12, 777-785. [CrossRef] [PubMed]

38. Dykens, J.A.; Jamieson, J.D.; Marroquin, L.D.; Nadanaciva, S.; Xu, J.J.; Dunn, M.C.; Smith, A.R.; Will, Y. In vitro assessment of mitochondrial dysfunction and cytotoxicity of nefazodone, trazodone, and buspirone. Toxicol. Sci. 2008, 103, 335-345. [CrossRef]

39. Yang, K.; Shrestha, S.; Zeng, H.; Karmaus, P.W.; Neale, G.; Vogel, P.; Guertin, D.A.; Lamb, R.F.; Chi, H. T cell exit from quiescence and differentiation into Th2 cells depend on Raptor-mTORC1-mediated metabolic reprogramming. Immunity 2013, 39, $1043-1056$. [CrossRef]

40. Zeng, H.; Chi, H. mTOR signaling and transcriptional regulation in T lymphocytes. Transcription 2014, 5, e28263. [CrossRef]

41. Wang, R.; Dillon, C.P.; Shi, L.Z.; Milasta, S.; Carter, R.; Finkelstein, D.; McCormick, L.L.; Fitzgerald, P.; Chi, H.; Munger, J.; et al. The transcription factor Myc controls metabolic reprogramming upon T lymphocyte activation. Immunity 2011, 35, 871-882. [CrossRef]

42. Tan, H.; Yang, K.; Li, Y.; Shaw, T.I.; Wang, Y.; Blanco, D.B.; Wang, X.; Cho, J.H.; Wang, H.; Rankin, S.; et al. Integrative proteomics and phosphoproteomics profiling reveals dynamic signaling networks and bioenergetics pathways underlying $\mathrm{T}$ cell activation. Immunity 2017, 46, 488-503. [CrossRef] [PubMed]

43. Kidani, Y.; Elsaesser, H.; Hock, M.B.; Vergnes, L.; Williams, K.J.; Argus, J.P.; Marbois, B.N.; Komisopoulou, E.; Wilson, E.B.; Osborne, T.F.; et al. Sterol regulatory element-binding proteins are essential for the metabolic programming of effector $\mathrm{T}$ cells and adaptive immunity. Nat. Immunol. 2013, 14, 489-499. [CrossRef] [PubMed]

44. Shimano, H.; Sato, R. SREBP-regulated lipid metabolism: Convergent physiology-divergent pathophysiology. Nat. Rev. Endocrinol. 2017, 13, 710-730. [CrossRef] [PubMed]

45. Semenza, G.L. Oxygen sensing, homeostasis, and disease. N. Engl. J. Med. 2011, 365, 537-547. [CrossRef]

46. Dang, E.V.; Barbi, J.; Yang, H.Y.; Jinasena, D.; Yu, H.; Zheng, Y.; Bordman, Z.; Fu, J.; Kim, Y.; Yen, H.R.; et al. Control of $\mathrm{T}(\mathrm{H}) 17 / \mathrm{T}(\mathrm{reg})$ balance by hypoxia-inducible factor 1. Cell 2011, 146, 772-784. [CrossRef] [PubMed]

47. Shi, L.Z.; Wang, R.; Huang, G.; Vogel, P.; Neale, G.; Green, D.R.; Chi, H. HIF1alpha-dependent glycolytic pathway orchestrates a metabolic checkpoint for the differentiation of TH17 and Treg cells. J. Exp. Med. 2011, 208, 1367-1376. [CrossRef] [PubMed]

48. Chang, C.H.; Curtis, J.D.; Maggi, L.B., Jr.; Faubert, B.; Villarino, A.V.; O'Sullivan, D.; Huang, S.C.; van der Windt, G.J.; Blagih, J.; Qiu, J.; et al. Posttranscriptional control of T cell effector function by aerobic glycolysis. Cell 2013, 153, 1239-1251. [CrossRef]

49. De Rosa, V.; Galgani, M.; Porcellini, A.; Colamatteo, A.; Santopaolo, M.; Zuchegna, C.; Romano, A.; De Simone, S.; Procaccini, C.; La Rocca, C.; et al. Glycolysis controls the induction of human regulatory T cells by modulating the expression of FOXP3 exon 2 splicing variants. Nat. Immunol. 2015, 16, 1174-1184. [CrossRef]

50. Bailis, W.; Shyer, J.A.; Zhao, J.; Canaveras, J.C.G.; Al Khazal, F.J.; Qu, R.; Steach, H.R.; Bielecki, P.; Khan, O.; Jackson, R.; et al. Distinct modes of mitochondrial metabolism uncouple T cell differentiation and function. Nature 2019, 571, 403-407. [CrossRef]

51. Leone, R.D.; Zhao, L.; Englert, J.M.; Sun, I.M.; Oh, M.H.; Sun, I.H.; Arwood, M.L.; Bettencourt, I.A.; Patel, C.H.; Wen, J.; et al. Glutamine blockade induces divergent metabolic programs to overcome tumor immune evasion. Science 2019, 366, $1013-1021$. [CrossRef]

52. Ahl, P.J.; Hopkins, R.A.; Xiang, W.W.; Au, B.; Kaliaperumal, N.; Fairhurst, A.M.; Connolly, J.E. Met-Flow, a strategy for single-cell metabolic analysis highlights dynamic changes in immune subpopulations. Commun. Biol. 2020, 3, 305. [CrossRef]

53. Segundo-Val, I.S.; Sanz-Lozano, C.S. Introduction to the gene expression analysis. Methods Mol. Biol. 2016, 1434, $29-43$.

54. Soh, K.T.; Wallace, P.K. RNA flow cytometry using the branched DNA technique. Methods Mol. Biol. 2018, 1678, 49-77. [PubMed]

55. Arrigucci, R.; Bushkin, Y.; Radford, F.; Lakehal, K.; Vir, P.; Pine, R.; Martin, D.; Sugarman, J.; Zhao, Y.; Yap, G.S.; et al. FISH-Flow, a protocol for the concurrent detection of mRNA and protein in single cells using fluorescence in situ hybridization and flow cytometry. Nat. Protoc. 2017, 12, 1245-1260. [CrossRef] [PubMed]

56. Banerjee, H.; Joyner, J.; Stevenson, M.; Kaha, W.; Krauss, C.; Hodges, S.; Santos, E.; Worthington, M.; Rousch, J.; Payne, G.; et al. Short communication: Studying the role of smart flare gold nano particles in studying micro RNA and oncogene differential expression in prostate cancer cell lines. J. Can. Res. Updates 2017, 6, 25-28. [CrossRef] [PubMed]

57. Lahm, H.; Doppler, S.; Dressen, M.; Werner, A.; Adamczyk, K.; Schrambke, D.; Brade, T.; Laugwitz, K.L.; Deutsch, M.A.; Schiemann, M.; et al. Live fluorescent RNA-based detection of pluripotency gene expression in embryonic and induced pluripotent stem cells of different species. Stem Cells 2015, 33, 392-402. [CrossRef]

58. Czarnek, M.; Bereta, J. SmartFlares fail to reflect their target transcripts levels. Sci. Rep. 2017, 7, 11682. [CrossRef]

59. McClellan, S.; Slamecka, J.; Howze, P.; Thompson, L.; Finan, M.; Rocconi, R.; Owen, L. mRNA detection in living cells: A next generation cancer stem cell identification technique. Methods 2015, 82, 47-54. [CrossRef] 
60. Seftor, E.A.; Seftor, R.E.B.; Weldon, D.; Kirsammer, G.T.; Margaryan, N.V.; Gilgur, A.; Hendrix, M.J.C. Melanoma tumor cell heterogeneity: A molecular approach to study subpopulations expressing the embryonic morphogen nodal. Semin. Oncol. 2014, 41, 259-266. [CrossRef] [PubMed]

61. Golab, K.; Krzystyniak, A.; Langa, P.; Pikula, M.; Kunovac, S.; Borek, P.; Trzonkowski, P.; Millis, J.M.; Fung, J.; Witkowski, P. Effect of serum on SmartFlare RNA Probes uptake and detection in cultured human cells. Biomed. J. Sci. Tech. Res. 2020, 28, $21788-21793$.

62. Saul, L.; Mair, I.; Ivens, A.; Brown, P.; Samuel, K.; Campbell, J.D.M.; Soong, D.Y.; Kamenjarin, N.; Mellanby, R.J. 1,25dihydroxyvitamin D3 restrains CD4(+) T cell priming ability of CD11c(+) dendritic cells by upregulating expression of CD31. Front. Immunol. 2019, 10, 600. [CrossRef] [PubMed]

63. Callender, L.A.; Carroll, E.C.; Bober, E.A.; Akbar, A.N.; Solito, E.; Henson, S.M. Mitochondrial mass governs the extent of human T cell senescence. Aging Cell 2020, 19, e13067. [CrossRef] [PubMed]

64. Durand, M.; Walter, T.; Pirnay, T.; Naessens, T.; Gueguen, P.; Goudot, C.; Lameiras, S.; Chang, Q.; Talaei, N.; Ornatsky, O.; et al. Human lymphoid organ cDC2 and macrophages play complementary roles in T follicular helper responses. J. Exp. Med. 2019, 216, 1561-1581. [CrossRef] [PubMed]

65. Frasca, D.; Diaz, A.; Romero, M.; Thaller, S.; Blomberg, B.B. Metabolic requirements of human pro-inflammatory B cells in aging and obesity. PLOS ONE 2019, 14, e0219545.

66. Ishifune, C.; Tsukumo, S.I.; Maekawa, Y.; Hozumi, K.; Chung, D.H.; Motozono, C.; Yamasaki, S.; Nakano, H.; Yasutomo, K. Regulation of membrane phospholipid asymmetry by Notch-mediated flippase expression controls the number of intraepithelial TCRalphabeta+CD8alphaalpha+ T cells. PLoS Biol. 2019, 17, e3000262. [CrossRef] [PubMed]

67. Schadt, L.; Sparano, C.; Schweiger, N.A.; Silina, K.; Cecconi, V.; Lucchiari, G.; Yagita, H.; Guggisberg, E.; Saba, S.; Nascakova, Z.; et al. Cancer-cell-intrinsic cGAS expression mediates tumor immunogenicity. Cell Rep. 2019, 29, 1236-1248. [CrossRef] [PubMed]

68. Akamatsu, M.; Mikami, N.; Ohkura, N.; Kawakami, R.; Kitagawa, Y.; Sugimoto, A.; Hirota, K.; Nakamura, N.; Ujihara, S.; Kurosaki, T.; et al. Conversion of antigen-specific effector/memory T cells into Foxp3-expressing Treg cells by inhibition of CDK8/19. Sci. Immunol. 2019, 4, eaaw2707. [CrossRef] [PubMed]

69. Mastelic-Gavillet, B.; Navarro Rodrigo, B.; Decombaz, L.; Wang, H.; Ercolano, G.; Ahmed, R.; Lozano, L.E.; Ianaro, A.; Derre, L.; Valerio, M.; et al. Adenosine mediates functional and metabolic suppression of peripheral and tumor-infiltrating CD8(+) T cells. J. Immunother. Cancer 2019, 7, 257. [CrossRef]

70. Rauschmeier, R.; Gustafsson, C.; Reinhardt, A.; A-Gonzalez, N.; Tortola, L.; Cansever, D.; Subramanian, S.; Taneja, R.; Rossner, M.J.; Sieweke, M.H.; et al. Bhlhe40 and Bhlhe41 transcription factors regulate alveolar macrophage self-renewal and identity. EMBO J. 2019, 38, e101233. [CrossRef] [PubMed]

71. Venken, K.; Jacques, P.; Mortier, C.; Labadia, M.E.; Decruy, T.; Coudenys, J.; Hoyt, K.; Wayne, A.L.; Hughes, R.; Turner, M.; et al. RORgammat inhibition selectively targets IL-17 producing iNKT and gammadelta-T cells enriched in Spondyloarthritis patients. Nat. Commun. 2019, 10, 9. [CrossRef]

72. Dickow, J.; Francois, S.; Kaiserling, R.L.; Malyshkina, A.; Drexler, I.; Westendorf, A.M.; Lang, K.S.; Santiago, M.L.; Dittmer, U.; Sutter, K. Diverse immunomodulatory effects of individual IFNalpha subtypes on virus-specific CD8(+) T cell responses. Front. Immunol. 2019, 10, 2255. [CrossRef]

73. Jiao, Y.; Ahmed, U.; Sim, M.F.M.; Bejar, A.; Zhang, X.; Talukder, M.M.U.; Rice, R.; Flannick, J.; Podgornaia, A.I.; Reilly, D.F.; et al. Discovering metabolic disease gene interactions by correlated effects on cellular morphology. Mol. Metab. 2019, 24, 108-119. [CrossRef] [PubMed]

74. Ram, D.R.; Manickam, C.; Hueber, B.; Itell, H.L.; Permar, S.R.; Varner, V.; Reeves, R.K. Tracking KLRC2 (NKG2C)+ memory-like NK cells in SIV+ and rhCMV+ rhesus macaques. PLoS Pathog. 2018, 14, e1007104. [CrossRef] [PubMed]

75. Jachetti, E.; Cancila, V.; Rigoni, A.; Bongiovanni, L.; Cappetti, B.; Belmonte, B.; Enriquez, C.; Casalini, P.; Ostano, P.; Frossi, B.; et al. Cross-talk between myeloid-derived suppressor cells and mast cells mediates tumor-specific immunosuppression in prostate cancer. Cancer Immunol. Res. 2018, 6, 552-565. [CrossRef] [PubMed]

76. Brajic, A.; Franckaert, D.; Burton, O.; Bornschein, S.; Calvanese, A.L.; Demeyer, S.; Cools, J.; Dooley, J.; Schlenner, S.; Liston, A. The long non-coding RNA flatr anticipates foxp3 expression in regulatory T cells. Front. Immunol. 2018, 9, 1989. [CrossRef]

77. Chongsathidkiet, P.; Jackson, C.; Koyama, S.; Loebel, F.; Cui, X.; Farber, S.H.; Woroniecka, K.; Elsamadicy, A.A.; Dechant, C.A.; Kemeny, H.R.; et al. Sequestration of T cells in bone marrow in the setting of glioblastoma and other intracranial tumors. Nat. Med. 2018, 24, 1459-1468. [CrossRef] [PubMed]

78. Richard, A.C.; Lun, A.T.L.; Lau, W.W.Y.; Gottgens, B.; Marioni, J.C.; Griffiths, G.M. T cell cytolytic capacity is independent of initial stimulation strength. Nat. Immunol. 2018, 19, 849-858. [CrossRef]

79. Chorazeczewski, J.K.; Aleshnick, M.; Majam, V.; Okoth, W.A.; Kurapova, R.; Akue, A.; Kukuruga, M.; Kumar, S.; Oakley, M.S. TCRbeta combinatorial immunoreceptor expression by neutrophils correlates with parasite burden and enhanced phagocytosis during a plasmodium berghei ANKA malaria infection. Infect. Immun. 2018, 86. [CrossRef]

80. Gomez, J.M.M.; Periasamy, P.; Dutertre, C.-A.; Irving, A.T.; Ng, J.H.J.; Crameri, G.; Baker, M.L.; Ginhoux, F.; Wang, L.F.; Alonso, S. Phenotypic and functional characterization of the major lymphocyte populations in the fruit-eating bat Pteropus alecto. Sci. Rep. 2016, 6, 37796. [CrossRef]

81. Taylor, E.B.; Moulana, M.; Stuge, T.B.; Quiniou, S.M.; Bengten, E.; Wilson, M. A Leukocyte immune-type receptor subset is a marker of antiviral cytotoxic cells in channel catfish, ictalurus punctatus. J. Immunol. 2016, 196, 2677-2689. [CrossRef] 
82. Wojno, E.D.; Monticelli, L.A.; Tran, S.V.; Alenghat, T.; Osborne, L.C.; Thome, J.J.; Willis, C.; Budelsky, A.; Farber, D.L.; Artis, D. The prostaglandin $\mathrm{D}(2)$ receptor $\mathrm{CRTH} 2$ regulates accumulation of group 2 innate lymphoid cells in the inflamed lung. Mucosal Immunol. 2015, 8, 1313-1323. [CrossRef]

83. Pacella, I.; Procaccini, C.; Focaccetti, C.; Miacci, S.; Timperi, E.; Faicchia, D.; Severa, M.; Rizzo, F.; Coccia, E.M.; Bonacina, F.; et al. Fatty acid metabolism complements glycolysis in the selective regulatory T cell expansion during tumor growth. Proc. Natl. Acad. Sci. USA 2018, 115, E6546-E6555. [CrossRef]

84. Piersma, S.J.; Pak-Wittel, M.A.; Lin, A.; Plougastel-Douglas, B.; Yokoyama, W.M. Activation receptor-dependent IFN-gamma production by NK cells is controlled by transcription, translation, and the proteasome. J. Immunol. 2019, 203, 1981-1988. [CrossRef] [PubMed]

85. Liu, J.; Zhang, X.; Chen, K.; Cheng, Y.; Liu, S.; Xia, M.; Chen, Y.; Zhu, H.; Li, Z.; Cao, X. CCR7 chemokine receptor-inducible lnc-dpf3 restrains dendritic cell migration by inhibiting HIF-1alpha-mediated glycolysis. Immunity 2019, 50, 600-615. [CrossRef]

86. Thornton, S.; Tan, R.; Sproles, A.; Do, T.; Schick, J.; Grom, A.A.; DeLay, M.; Schulert, G.S. A Multiparameter flow cytometry analysis panel to assess CD163 mRNA and protein in monocyte and macrophage populations in hyperinflammatory diseases. $J$. Immunol. 2019, 202, 1635-1643. [CrossRef] [PubMed]

87. Harrison, O.J.; Linehan, J.L.; Shih, H.Y.; Bouladoux, N.; Han, S.J.; Smelkinson, M.; Sen, S.K.; Byrd, A.L.; Enamorado, M.; Yao, C.; et al. Commensal-specific T cell plasticity promotes rapid tissue adaptation to injury. Science 2019, 363. [CrossRef] [PubMed]

88. Groves, C.J.; Carrell, J.; Grady, R.; Rajan, B.; Morehouse, C.A.; Halpin, R.; Wang, J.; Wu, J.; Shrestha, Y.; Rayanki, R.; et al. CD19-positive antibody-secreting cells provide immune memory. Blood Adv. 2018, 2, 3163-3176. [CrossRef] [PubMed]

89. Li, B.; Jones, L.L.; Geiger, T.L. IL-6 promotes T cell proliferation and expansion under inflammatory conditions in association with low-level RORgammat expression. J. Immunol. 2018, 201, 2934-2946. [CrossRef]

90. Dam, E.M.; Maier, A.C.; Hocking, A.M.; Carlin, J.; Ng, B.; Buckner, J.H. Increased binding of specificity protein 1 to the IL21R promoter in B cells results in enhanced b cell responses in rheumatoid arthritis. Front. Immunol. 2018, 9, 1978. [CrossRef] [PubMed]

91. Iglesias, M.; Arun, A.; Chicco, M.; Lam, B.; Talbot, C.C., Jr.; Ivanova, V.; Lee, W.P.A.; Brandacher, G.; Raimondi, G. Type-I interferons inhibit interleukin-10 signaling and favor type 1 diabetes development in nonobese diabetic mice. Front. Immunol. 2018, 9, 1565. [CrossRef]

92. Oakley, M.S.; Chorazeczewski, J.K.; Aleshnick, M.; Anantharaman, V.; Majam, V.; Chawla, B.; Myers, T.G.; Su, Q.; Okoth, W.A.; Takeda, K.; et al. TCRbeta-expressing macrophages induced by a pathogenic murine malaria correlate with parasite burden and enhanced phagocytic activity. PLoS ONE 2018, 13, e0201043. [CrossRef]

93. Hilvering, B.; Hinks, T.S.C.; Stoger, L.; Marchi, E.; Salimi, M.; Shrimanker, R.; Liu, W.; Chen, W.; Luo, J.; Go, S.; et al. Synergistic activation of pro-inflammatory type-2 CD8(+) T lymphocytes by lipid mediators in severe eosinophilic asthma. Mucosal Immunol. 2018, 11, 1408-1419. [CrossRef]

94. Manickam, C.; Nwanze, C.; Ram, D.R.; Shah, S.V.; Smith, S.; Jones, R.; Hueber, B.; Kroll, K.; Varner, V.; Goepfert, P.; et al. Progressive lentivirus infection induces natural killer cell receptor-expressing B cells in the gastrointestinal tract. AIDS 2018, 32, 1571-1578. [CrossRef]

95. Akeus, P.; Szeponik, L.; Ahlmanner, F.; Sundstrom, P.; Alsen, S.; Gustavsson, B.; Sparwasser, T.; Raghavan, S.; Quiding-Jarbrink, M. Regulatory T cells control endothelial chemokine production and migration of T cells into intestinal tumors of APC(min/+) mice. Cancer Immunol. Immunother. 2018, 67, 1067-1077. [CrossRef]

96. Lubelsky, Y.; Ulitsky, I. Sequences enriched in Alu repeats drive nuclear localization of long RNAs in human cells. Nature 2018, 555, 107-111. [CrossRef]

97. Pellefigues, C.; Dema, B.; Lamri, Y.; Saidoune, F.; Chavarot, N.; Loheac, C.; Pacreau, E.; Dussiot, M.; Bidault, C.; Marquet, F.; et al. Prostaglandin D2 amplifies lupus disease through basophil accumulation in lymphoid organs. Nat. Commun. 2018, 9, 725. [CrossRef]

98. Bottcher, J.P.; Bonavita, E.; Chakravarty, P.; Blees, H.; Cabeza-Cabrerizo, M.; Sammicheli, S.; Rogers, N.C.; Sahai, E.; Zelenay, S.; Reis, E.S.C. NK cells stimulate recruitment of $\mathrm{cDC1}$ into the tumor microenvironment promoting cancer immune control. Cell 2018, 172, 1022-1037. [CrossRef] [PubMed]

99. Li, J.; Bhattacharya, S.; Zhou, J.; Phadnis-Moghe, A.S.; Crawford, R.B.; Kaminski, N.E. Aryl hydrocarbon receptor activation suppresses EBF1 and PAX5 and impairs human B lymphopoiesis. J. Immunol. 2017, 199, 3504-3515. [CrossRef] [PubMed]

100. Akimova, T.; Zhang, T.; Negorev, D.; Singhal, S.; Stadanlick, J.; Rao, A.; Annunziata, M.; Levine, M.H.; Beier, U.H.; Diamond, J.M.; et al. Human lung tumor FOXP3+ Tregs upregulate four “Treg-locking” transcription factors. JCI Insight 2017, 2, e94075. [CrossRef] [PubMed]

101. Zhang, T.T.; Gonzalez, D.G.; Cote, C.M.; Kerfoot, S.M.; Deng, S.; Cheng, Y.; Magari, M.; Haberman, A.M. Germinal center B cell development has distinctly regulated stages completed by disengagement from T cell help. Elife 2017, 6, e19552. [CrossRef] [PubMed]

102. Yi, J.S.; Russo, M.A.; Massey, J.M.; Juel, V.; Hobson-Webb, L.D.; Gable, K.; Raja, S.M.; Balderson, K.; Weinhold, K.J.; Guptill, J.T. B10 cell frequencies and suppressive capacity in myasthenia gravis are associated with disease severity. Front. Neurol. 2017, 8, 34. [CrossRef] [PubMed] 
103. Venable, A.S.; Henning, A.L.; Prado, E.A.; McFarlin, B.K. Using image-based flow cytometry with a FISH-based flowRNA assay to simultaneously detect intracellular TNF-alpha protein and mRNA in monocytes following LPS stimulation. Methods Mol. Biol. 2016, 1389, 139-151. [PubMed]

104. Henning, A.L.; Sampson, J.N.B.; McFarlin, B.K. Measurement of low-abundance intracellular mRNA using amplified FISH staining and image-based flow cytometry. Curr. Protoc. Cytom. 2016, 76, 7-46. [CrossRef]

105. Grau-Exposito, J.; Luque-Ballesteros, L.; Navarro, J.; Curran, A.; Burgos, J.; Ribera, E.; Torrella, A.; Planas, B.; Badia, R.; MartinCastillo, M.; et al. Latency reversal agents affect differently the latent reservoir present in distinct CD4+ T subpopulations. PLoS Pathog. 2019, 15, e1007991. [CrossRef] [PubMed]

106. Bertram, K.M.; Botting, R.A.; Baharlou, H.; Rhodes, J.W.; Rana, H.; Graham, J.D.; Patrick, E.; Fletcher, J.; Plasto, T.M.; Truong, N.R.; et al. Identification of HIV transmitting CD11c(+) human epidermal dendritic cells. Nat. Commun. 2019, 10, 2759. [CrossRef] [PubMed]

107. Sinigaglia, L.; Gracias, S.; Decembre, E.; Fritz, M.; Bruni, D.; Smith, N.; Herbeuval, J.P.; Martin, A.; Dreux, M.; Tangy, F.; et al. Immature particles and capsid-free viral RNA produced by Yellow fever virus-infected cells stimulate plasmacytoid dendritic cells to secrete interferons. Sci. Rep. 2018, 8, 10889. [CrossRef]

108. Rao, S.; Amorim, R.; Niu, M.; Temzi, A.; Mouland, A.J. The RNA surveillance proteins UPF1, UPF2 and SMG6 affect HIV-1 reactivation at a post-transcriptional level. Retrovirology 2018, 15, 42. [CrossRef]

109. Richard, J.; Prevost, J.; Baxter, A.E.; von Bredow, B.; Ding, S.; Medjahed, H.; Delgado, G.G.; Brassard, N.; Sturzel, C.M.; Kirchhoff, F.; et al. Uninfected bystander cells impact the measurement of HIV-specific antibody-dependent cellular cytotoxicity responses. mBio 2018, 9. [CrossRef]

110. Baxter, A.E.; Niessl, J.; Fromentin, R.; Richard, J.; Porichis, F.; Massanella, M.; Brassard, N.; Alsahafi, N.; Routy, J.P.; Finzi, A.; et al. Multiparametric characterization of rare HIV-infected cells using an RNA-flow FISH technique. Nat. Protoc. 2017, 12, 2029-2049. [CrossRef]

111. McHugh, D.; Caduff, N.; Barros, M.H.M.; Ramer, P.C.; Raykova, A.; Murer, A.; Landtwing, V.; Quast, I.; Styles, C.T.; Spohn, M.; et al. Persistent KSHV infection increases EBV-associated tumor formation in vivo via enhanced EBV lytic gene expression. Cell Host Microbe 2017, 22, 61-73. [CrossRef]

112. Grau-Exposito, J.; Serra-Peinado, C.; Miguel, L.; Navarro, J.; Curran, A.; Burgos, J.; Ocana, I.; Ribera, E.; Torrella, A.; Planas, B.; et al. A novel single-cell FISH-flow assay identifies effector memory CD4(+) T cells as a major niche for HIV-1 transcription in HIV-infected patients. mBio 2017, 8. [CrossRef] [PubMed]

113. Falkenberg, S.M.; Dassanayake, R.P.; Neill, J.D.; Ridpath, J.F. Improved detection of bovine viral diarrhea virus in bovine lymphoid cell lines using PrimeFlow RNA assay. Virology 2017, 509, 260-265. [CrossRef] [PubMed]

114. Douam, F.; Hrebikova, G.; Albrecht, Y.E.; Sellau, J.; Sharon, Y.; Ding, Q.; Ploss, A. Single-cell tracking of flavivirus RNA uncovers species-specific interactions with the immune system dictating disease outcome. Nat. Commun. 2017, 8, 14781. [CrossRef]

115. Malmhall, C.; Weidner, J.; Radinger, M. MicroRNA-155 expression suggests a sex disparity in innate lymphoid cells at the single-cell level. Cell Mol. Immunol. 2020, 17, 544-546. [CrossRef] [PubMed]

116. Lyszkiewicz, M.; Winter, S.J.; Witzlau, K.; Fohse, L.; Brownlie, R.; Puchalka, J.; Verheyden, N.A.; Kunze-Schumacher, H.; Imelmann, E.; Blume, J.; et al. miR-181a/b-1 controls thymic selection of Treg cells and tunes their suppressive capacity. PLoS Biol. 2019, 17, e2006716. [CrossRef] [PubMed]

117. Gustafson, C.E.; Cavanagh, M.M.; Jin, J.; Weyand, C.M.; Goronzy, J.J. Functional pathways regulated by microRNA networks in CD8 T-cell aging. Aging Cell 2019, 18, e12879. [CrossRef]

118. Lai, C.; Stepniak, D.; Sias, L.; Funatake, C. A sensitive flow cytometric method for multi-parametric analysis of microRNA, messenger RNA and protein in single cells. Methods 2018, 134-135, 136-148. [CrossRef]

119. Smith, S.; Fernando, T.; Wu, P.W.; Seo, J.; Ni Gabhann, J.; Piskareva, O.; McCarthy, E.; Howard, D.; O'Connell, P.; Conway, R.; et al. MicroRNA-302d targets IRF9 to regulate the IFN-induced gene expression in SLE. J. Autoimmun. 2017, 79, 105-111. [CrossRef] [PubMed]

120. Porichis, F.; Hart, M.G.; Griesbeck, M.; Everett, H.L.; Hassan, M.; Baxter, A.E.; Lindqvist, M.; Miller, S.M.; Soghoian, D.Z.; Kavanagh, D.G.; et al. High-throughput detection of miRNAs and gene-specific mRNA at the single-cell level by flow cytometry. Nat. Commun. 2014, 5, 5641. [CrossRef] [PubMed]

121. Bruni, D.; Angell, H.K.; Galon, J. The immune contexture and Immunoscore in cancer prognosis and therapeutic efficacy. Nat. Rev. Cancer 2020, 20, 662-680. [CrossRef] [PubMed]

122. Roychoudhuri, R.; Eil, R.L.; Restifo, N.P. The interplay of effector and regulatory T cells in cancer. Curr. Opin. Immunol. 2015, 33, 101-111. [CrossRef]

123. Ayala, M.A.M.; Li, Z.; DuPage, M. Treg programming and therapeutic reprogramming in cancer. Immunology 2019, 157, 198-209. [CrossRef] [PubMed]

124. Magnuson, A.M.; Kiner, E.; Ergun, A.; Park, J.S.; Asinovski, N.; Ortiz-Lopez, A.; Kilcoyne, A.; Paoluzzi-Tomada, E.; Weissleder, R.; Mathis, D.; et al. Identification and validation of a tumor-infiltrating Treg transcriptional signature conserved across species and tumor types. Proc. Natl. Acad. Sci. USA 2018, 115, E10672-E10681. [CrossRef] [PubMed]

125. Hu, Y.; Wang, C.; Li, Y.; Zhao, J.; Chen, C.; Zhou, Y.; Tao, Y.; Guo, M.; Qin, N.; Ren, T.; et al. MiR-21 controls in situ expansion of CCR6(+) regulatory T cells through PTEN/AKT pathway in breast cancer. Immunol. Cell. Biol. 2015, 93, 753-764. [CrossRef] 
126. Li, C.; Zhu, B.; Son, Y.M.; Wang, Z.; Jiang, L.; Xiang, M.; Ye, Z.; Beckermann, K.E.; Wu, Y.; Jenkins, J.W.; et al. The transcription factor Bhlhe40 programs mitochondrial regulation of resident CD8(+) T cell fitness and functionality. Immunity 2019, 51, 491-507 e7. [CrossRef]

127. Zheng, C.; Zheng, L.; Yoo, J.K.; Guo, H.; Zhang, Y.; Guo, X.; Kang, B.; Hu, R.; Huang, J.Y.; Zhang, Q.; et al. Landscape of infiltrating T cells in liver cancer revealed by single-cell sequencing. Cell 2017, 169, 1342-1356. [CrossRef]

128. Piconese, S.; Timperi, E.; Pacella, I.; Schinzari, V.; Tripodo, C.; Rossi, M.; Guglielmo, N.; Mennini, G.; Grazi, G.L.; Di Filippo, S.; et al. Human OX40 tunes the function of regulatory T cells in tumor and nontumor areas of hepatitis $C$ virus-infected liver tissue. Hepatology 2014, 60, 1494-1507. [CrossRef] [PubMed]

129. Timperi, E.; Pacella, I.; Schinzari, V.; Focaccetti, C.; Sacco, L.; Farelli, F.; Caronna, R.; Del Bene, G.; Longo, F.; Ciardi, A.; et al. Regulatory $\mathrm{T}$ cells with multiple suppressive and potentially pro-tumor activities accumulate in human colorectal cancer. Oncoimmunology 2016, 5, e1175800. [CrossRef] [PubMed]

130. Mot, A.I.; Liddell, J.R.; White, A.R.; Crouch, P.J. Circumventing the crabtree effect: A method to induce lactate consumption and increase oxidative phosphorylation in cell culture. Int. J. Biochem. Cell Biol. 2016, 79, 128-138. [CrossRef] [PubMed]

131. Piconese, S.; Pittoni, P.; Burocchi, A.; Gorzanelli, A.; Care, A.; Tripodo, C.; Colombo, M.P. A non-redundant role for OX40 in the competitive fitness of Treg in response to IL-2. Eur. J. Immunol. 2010, 40, 2902-2913. [CrossRef] [PubMed]

132. Burkhardt, J.K.; Carrizosa, E.; Shaffer, M.H. The actin cytoskeleton in T cell activation. Annu. Rev. Immunol. 2008, 26, 233-259. [CrossRef] [PubMed] 